\title{
STRATEGIC FORCES IN THE CZECH BREWING INDUSTRY FROM 1990-2015
}

\section{Stanislav Tripes, Jiří Dvořák*}

\begin{abstract}
The need for this research stems from the dynamic development that the brewing industry has undergone since the Velvet Revolution when the market was split between seventy-one regional breweries. In the 1990s, customers began to prefer the larger nationwide breweries, a trend that led to the bankruptcy of some regional breweries thereby creating a market niche that was quickly filled by microbreweries. By 2015, there were 44 industrial breweries and around 300 microbreweries. By then, the beer market had diversified, and since the brewing industry had been highly dynamic, managers had to change strategy regarding customer requirements. Strategic change has since been reflected in the pricing and quality of the beer, marketing communication, and merchandising. Knowledge of developments in the industry and adapting strategies to meet these changes have been key factors in determining future survival. The purpose of this study is to describe the development of the brewing industry and the resulting strategic changes of different breweries. Historical knowledge is required for future research into the perception of the brewery managers' strategic thinking. This paper is the first step in longitudinal research focused on strategy formulation at the business level in the brewing industry and brewery performance. The study is based on qualitative approaches and a two-step research design: the first phase is historical research, where the data was obtained from contemporary newspapers, professional and scientific journals, and annual reports from breweries. The second phase is composed of interviews conducted at four breweries, which are representative of the population. The results of this study help to clarify industry behaviour and are intended as a source of knowledge that practitioners can use in their strategic decision-making process. The study reflects previous industry behaviour and describes current trends in customer requirements that can be used when forming a business level strategy and identifying an appropriate generic strategy.
\end{abstract}

Keywords: industry development, breweries, generic strategy, Czech Republic JEL Classification: M10, N30, L10

\section{Introduction}

The Czech brewing industry and Czech beer are world-renowned and regarded by many beer drinkers as the best. The domestic production strategies and export strategies of Czech breweries have undergone dynamic development in the last twenty-five 25 years. This

* University of Economics, Prague, Faculty of Management, J. Hradec (tripes@fm.vse.cz; dvorakji@ fm.vse.cz). 
development is connected to the Czech Republic's economic transformation following the Velvet Revolution in 1989. Previously governed by a state-driven economy, the subsequent privatisation of the brewing industry after the Velvet Revolution proved to be the catalyst for competitor fights throughout the entire industry, thereby making strategic thinking compulsory. Different approaches to selling beer, which incorporated low-cost or generic differentiation strategies [Porter, 2008] were used throughout this period.

This study focuses on historical research into the development of the brewing industry from a strategic point of view. The pricing approaches, beer typology and quality, customer requirements, competitor behaviour, market structure (the rise and fall of breweries), ownership takeovers, and marketing have undergone immense change within the industry. The research issue examined in this study identifies the factors that influenced the strategic choices at that time. Czech managers have now learned management practices and strategy formulation although their previous decision-making processes were sometimes without analyses, which resulted in extensive problems and the closure of breweries. This historical study identifies the causes and consequences of their strategic managerial decisions.

Academic discussion of the brewing industry is an underdeveloped research topic. There is a lack of studies describing strategy development in the brewing industry. The development of the brewing industry in the EU was described by Larimo et al. [2006] and for the Czech Republic by Janda \& Mikolasek [2011], and Pulec [2016]. All describe the development of the industry in general or in connection with the post-transformation development of CEE countries. Stellner \& Polanecky [2016], on the other hand, are locally oriented, and their study discusses the development of breweries in South Bohemia as a specific region of the Czech Republic. The economics of beer processing were studied by Chmelikova \& Sabolovic [2012]. None of the studies mentioned discuss strategy. The only studies that partially discussed strategy were Žufan and his colleagues [Pyšný \& Žufan, 2006; Syrovátka et al., 2015; Žufan \& Erbes, 2002; Žufan \& Pyšný, 2005] and Marinov \& Marinova [2015], who described marketing approaches in CEE countries. However, they focused on transnational breweries and groups. Marketing strategies have been discussed from an internationalisation point of view and the global-local dilemma of marketing strategy. Nevertheless, Czech customers are well known for beer loyalty and do not prefer foreign beer. The strategy of Czech breweries can also be seen in social studies elaborated by Vinopal [2014; 2015], who described the perception of the beer market by customers and also focused on beer mixes (beer mixed with a soft drink). His study helps clarify customer requirements, which have markedly changed over the last 15 years. The microbrewery boom settled on this change [Maier, 2013; Vacl, 2014], which caused turbulence in the Czech beer industry. The change also became evident in pricing [Maier, 2012; Maier \& Fabianova, 2011], where the large breweries frequently pursued a low-cost strategy. Mini and microbreweries have tried to compete using the same tools although recently have favoured the differentiation strategy. Although the mentioned studies provide a useful form of familiarisation with the Czech brewing industry, they do not provide an overall picture.

The significance of the study can be seen in the historical consequences of the industry's development and the strategic choice of a particular brewery. History has shown that many breweries made poor strategic decisions and, as a result, went bankrupt. This study shows the development of customer and market behaviour reflected in the breweries' strategies. Knowledge of customers, competitors, and other stakeholders is vital to strategy 
formulation [Freeman, 2010], especially in a dynamic industry. The dynamics can be hidden by rapid changes in customer requirements, ownership, and price wars - factors that should be reflected in a strategy [García \& Car, 2009; Kleban \& Nickerson, 2012; Sveiby et al., 2002]. Nevertheless, history shows that strategic mistakes were made. The main aim of this paper is to show the consequences of the strategic mistakes that bankrupted breweries.

Two research questions were formulated:

RQ1: What were the main forces in the brewing industry during the past 25 years?

RQ2: Which strategic mistakes caused the bankruptcy of breweries?

\section{Methodology}

The qualitative approach was incorporated in the form of historical research, which is considered to be the most useful form for acquiring knowledge of the industry's development [Andrew et al., 2011; Grbich, 2012] over the last 26 years. Primary and secondary sources were analysed. Newspaper articles were found on the Anopress IT server, where Czech newspapers, magazines, and TV and radio broadcasts are saved [Anopress IT, 2016]. The keywords brewery, brewing industry and strategy were used as search terms. The Anopress tool found more than 1,000 articles and news stories. Local events and one-off brewery-oriented news items were excluded from the list. The goal of this search was to find articles that described the entire industry. Journal articles were searched via the EBSCO and ProQuest Central databases licensed by the University of Economics Prague. Statistical data was collected from the websites of the Czech Statistical Office, the Czech Union of Breweries and Malthouses, the Brewers of Europe and the Customs Office of the Czech Republic. The problem with the statistical data was that it was incomplete for the whole period and sometimes the datasets did not correspond with each other. We used what we considered to be the most appropriate data and validated it from other sources.

Brewery managers were interviewed as the primary source for validating our findings. The research sample was comprised of four managers covering the brewery population according to size - mini, small, medium-sized, and nationwide breweries. These managers were selected based on the authors' and their acquaintances' contacts. All the respondents had been working in the brewing industry since 1990 or longer and possessed accurate knowledge of the development of the industry. The form of each interview was a combination of a narrative and a semi-structured interview.

The data was analysed using NVivo 11 software for qualitative data analysis, where all data was transcribed and nineteen nodes (categories) were created using open coding wherever important issues appeared. All the sources were coded according to the nodes, organised by the date of source origin and the date discussed to formulate a timeline. The coded data was thoroughly analysed and sorted into subcategories - causal events contributing to the phenomenon; descriptive details of the phenomenon itself; and the ramifications of the phenomenon [Edwards \& Skinner, 2010; Hendl, 2005]. The interpretation of coding was based on the knowledge of strategic management theory and environmental forces. The findings were validated using the results of the interviews with the brewery managers. 


\section{The brewing industry in the Czech Republic}

The history of Europe, and the Czech Republic by extension, has been closely associated with the development of brewing since the early Middle Ages [Kratochvíle, 2005; Řeboun, 2013; Zýbrt, 2005]. The brewing industry evolved alongside human society, where products are closely tied to cultural practices. More than 3,000 breweries have been founded in the area of the Czech Republic [Bělohoubek, 1874] and the number is still growing, resulting in constant attention [Řeboun, 2013]. The rulers of the different levels of society were well aware of this as evidenced by the system of brewing rights developed in many countries, which has been widely used as a source of revenue and as a political tool. The brewing industry is strongly influenced by the political situation.

The Czech brewing industry encountered two World Wars and the Communist era in the twentieth century. There were 700 breweries in operation before the Czechoslovak Republic was established and 526 active breweries in 1918 [Chládek, 2007; Němec, 2014].

Figure 1 | Breweries in the Czech Republic

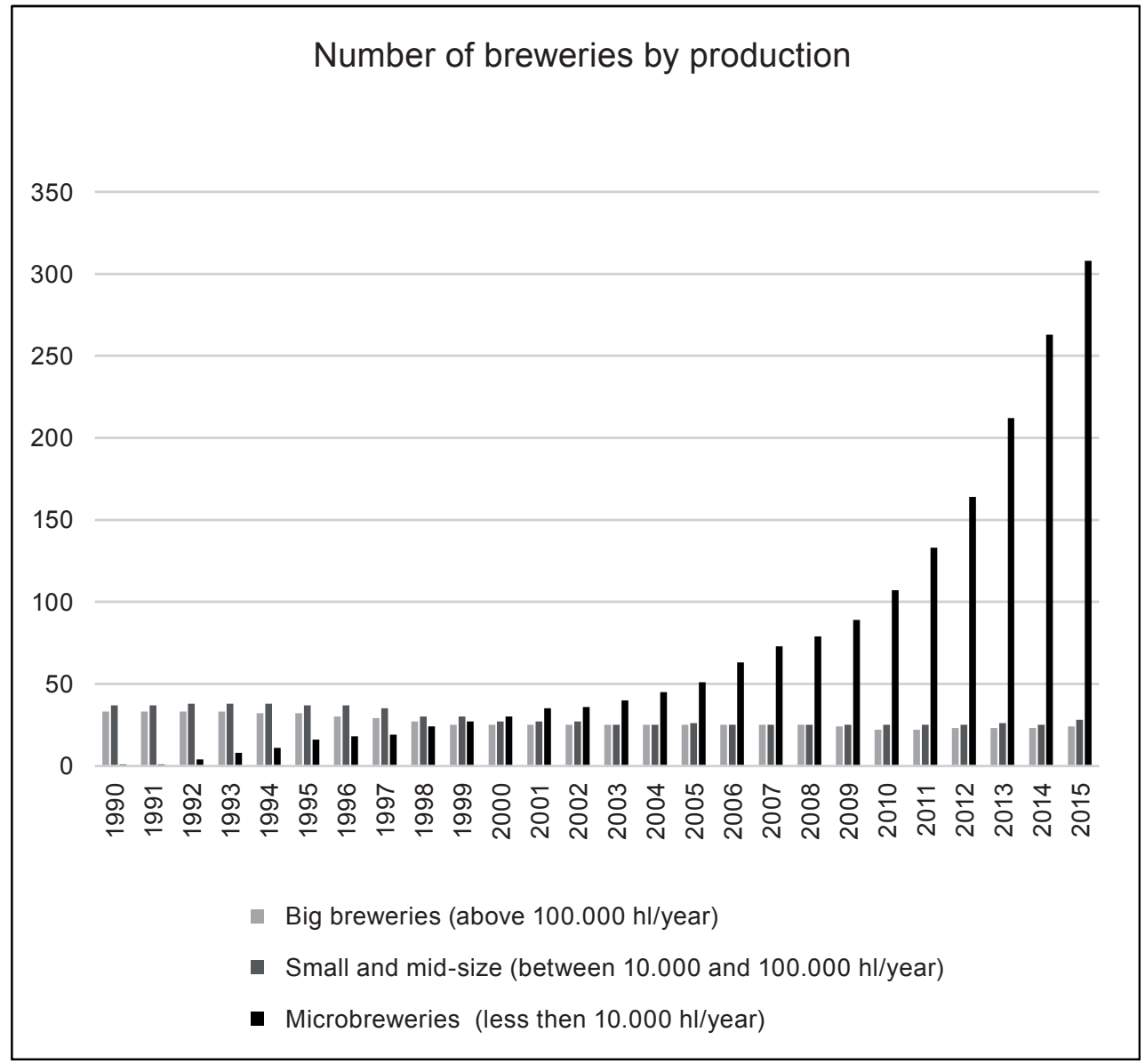

Source: authors' own calculations 
The end of the First World War and the lack of raw materials exacerbated the situation. During the First Republic, the industry was consolidated and the gradual concentration resulted in the closure of 174 breweries [Basařová \& Hlaváček, 1998]. During the Second World War, the industry was heavily damaged again and the first wave of nationalisations by virtue of Presidential Decree No. 101/1945 dated 24 October 1945 was implemented after 1945. The limit for nationalisation was set at an annual production of above 150,000 hectolitres in 1937 and the first five national companies were established based on this decree [Basařová \& Hlaváček, 1998]. The total number of breweries was further reduced to 71 during subsequent concentration of the industry in the second half of the twentieth century and these were subsequently incorporated into one holding structure in 1975. The breweries suffered from the same problems as most other industries at the time. The lack of investment and the hidden indebtedness of these enterprises significantly deteriorated their starting position for future privatisation and entry to the market economy. There were only 71 breweries in the whole of Czechoslovakia after the Velvet Revolution [Němec, 2014].

The end of the Communist era sparked a dynamic development in the brewing industry. Figures supporting this affirmation are shown in Figure 1 and Table 1. The development of the brewing industry is divided into three key periods: the 1990s, the beginning of the new millennium, and 2010 to the present. Much has happened throughout these periods; the 1990s were characterised by acquisitions and mergers by foreign investors and price wars raged during the late 1990s, which caused medium-sized breweries to close [Maier, 2013]. The new millennium encountered price wars once again along with the microbrewery boom, which started in 2005 and followed the pattern of US microbreweries [Maier, 2013; Němec, 2014; Petr, 2010a; Vacl, 2014]. The last period was strongly influenced by the economic crisis in 2009 , which caused a rapid decrease in consumer consumption and led to later changes in requirements. The typical consumption of standard premium beers has since decreased and special beers have now become popular.

The terminology of beer types is perceived differently in the Czech Republic, which therefore makes it necessary to define the types of beer discussed in this paper. Consequently, only three simplified product categories are used.

1. Light beers, less than $11 \%$ of original wort extract (OWE).

2. Premium beers, $11 \%-12.99 \%$ OWE.

3. Other beers, $13 \%$ OWE or more and flavoured beers.

The original wort extract percentage refers to the sugar content during alcohol fermentation and is often referred to as the "size" of the beer. The Plato Scale $\left({ }^{\circ} \mathrm{P}\right)$ is a historical scale used unofficially in the Czech Republic and is similar but less exact than the wort extract percentage. 
Table 1 | Industry overview in numbers

\begin{tabular}{|c|c|c|c|c|c|c|c|}
\hline \multirow[t]{2}{*}{ Year } & \multirow{2}{*}{$\begin{array}{c}\text { Beer } \\
\text { production } \\
(1,000 \mathrm{hl})\end{array}$} & \multirow{2}{*}{\begin{tabular}{|c|} 
Beer \\
export \\
$(1,000 \mathrm{hl})$
\end{tabular}} & \multirow{2}{*}{ 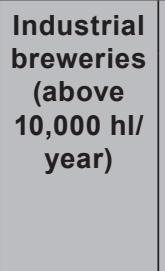 } & \multirow{2}{*}{$\begin{array}{c}\text { Micro- } \\
\text { breweries } \\
\text { (less than } \\
10,000 \mathrm{hl} / \\
\text { year) }\end{array}$} & \multicolumn{3}{|c|}{ Categories of beer production $\%$} \\
\hline & & & & & $\begin{array}{c}\text { Light } \\
\text { beers, } \\
\text { less } \\
\text { than } \\
11 \% \\
\text { OWE }\end{array}$ & $\begin{array}{c}\text { Premium } \\
\text { beers, } \\
11 \%- \\
12.99 \% \\
\text { OWE }\end{array}$ & $\begin{array}{c}\text { Other } \\
\text { beers, } 13 \% \\
\text { OWE or } \\
\text { more and } \\
\text { flavoured } \\
\text { beer }\end{array}$ \\
\hline 1990 & 19,199 & 1,934 & 70 & 1 & 38.9 & 59.8 & 1.3 \\
\hline 1991 & 18,297 & 2,487 & 70 & 1 & 52.9 & 45.9 & 1.2 \\
\hline 1992 & 19,464 & 2,259 & 71 & 4 & 57.7 & 40.9 & 1.4 \\
\hline 1993 & 17,804 & 1,771 & 71 & 8 & 64.6 & 34.9 & 0.5 \\
\hline 1994 & 18,041 & 1,418 & 70 & 11 & 64.9 & 34.1 & 1.0 \\
\hline 1995 & 17,838 & 1,403 & 69 & 16 & 65.1 & 34.3 & 0.6 \\
\hline 1996 & 18,242 & 1,791 & 67 & 18 & 64.5 & 34.8 & 0.6 \\
\hline 1997 & 18,649 & 1,954 & 64 & 19 & 62.9 & 35.9 & 1.1 \\
\hline 1998 & 18,292 & 1,749 & 57 & 24 & 64.1 & 34.5 & 1.4 \\
\hline 1999 & 17,863 & 1,401 & 55 & 27 & 64.6 & 33.6 & 1.8 \\
\hline 2000 & 17,925 & 1,589 & 52 & 30 & 65.0 & 34.0 & 1.0 \\
\hline 2001 & 17,881 & 1,855 & 52 & 35 & 64.8 & 33.6 & 1.6 \\
\hline 2002 & 18,178 & 1,975 & 52 & 36 & 64.0 & 34.3 & 1.7 \\
\hline 2003 & 18,548 & 2,130 & 50 & 40 & 64.9 & 34.0 & 1.1 \\
\hline 2004 & 18,753 & 2,638 & 50 & 45 & 64.4 & 34.4 & 1.2 \\
\hline 2005 & 19,069 & 3,099 & 51 & 51 & 62.9 & 35.8 & 1.2 \\
\hline 2006 & 19,787 & 3,536 & 50 & 63 & 65.2 & 32.4 & 2.4 \\
\hline 2007 & 19,800 & 2,234 & 50 & 73 & 64.0 & 32.7 & 3.3 \\
\hline 2008 & 19,800 & 2,652 & 50 & 79 & 62.2 & 33.8 & 4.1 \\
\hline 2009 & 19,877 & 2,834 & 49 & 89 & 58.9 & 36.7 & 4.4 \\
\hline 2010 & 18,098 & 1,981 & 47 & 107 & 56.7 & 38.7 & 4.6 \\
\hline 2011 & 18,624 & 2,540 & 47 & 133 & 55.2 & 39.7 & 5.1 \\
\hline 2012 & 19,216 & 2,732 & 48 & 164 & 53.4 & 41.9 & 4.7 \\
\hline 2013 & 19,205 & 2,892 & 49 & 212 & 52.2 & 43.3 & 4.5 \\
\hline 2014 & 19,648 & 3,361 & 48 & 263 & 50.6 & 43.9 & 5.5 \\
\hline 2015 & 20,076 & 3,827 & 52 & 308 & 47.2 & 46.6 & 6.5 \\
\hline Average & 18,776 & 2,309 & & & 59.7 & 37.9 & 2.5 \\
\hline
\end{tabular}

Source: authors' own calculations from the Czech Statistical Office, company web pages, the Czech Union of Breweries and Malthouses, the Brewers of Europe, and the Customs Office of the Czech Republic. 


\subsection{The 1990s}

A new stage in the development of Czech brewing began after 1989. The political change was associated with positive expectations, including this sector [Greenhouse, 1990], which formed a large part of the Czech economy. The Czech brewing industry held the leading position in beer consumption per capita - around 160 litres per year [Cook, 1999; Janda \& Mikolasek, 2011; Newberry, 1993]. Therefore, any changes were closely monitored by both the general public and politicians. Beer was perceived as a local product that was mostly independent of foreign inputs and the whole industry was relatively stable and profitable with the potential for export. A major impulse for foreign investors, which affected the relative stability of the sector, was the abolition of the centrally directed control of the sector and this resulted in a gradual change in ownership structures during the 1990s [Kratochvíle, 2005]. The primary impulse was the voucher privatisation system under which the majority of breweries were privatised [Stellner \& Polanecký, 2016]. Further privatisation steps were influenced by foreign investors who took an interest in large breweries with a fragmented ownership structure or those still under state ownership [Kratochvíle, 2005]. The main reason for the entry of foreign investors can be seen in the existence of relatively valuable brands with potentially lucrative market shares and considerable export potential [King \& Murray, 1994; Murray, 1995].

Foreign investors first entered the Czech brewing industry in 1994. The Austrian BBAG bought the Starobrno Brewery followed by the sale of more than half of the shares of Prague Breweries to the British Bass Company in 1996 [Rocks, 1997]. Many of the large breweries were privatised by voucher privatisation, thus the investment funds generated under the scheme actively participated in the further transfers of assets. These were mostly portfolio investors, often connected with large state-owned banks, who showed a lack of interest in building a long-term strategy of owning a company while the stake was largely viewed as a relatively liquid and potentially profitable part of the portfolio. The Investiční a poštovní banka (IPB - Investment and Post Office Bank) and its investment funds were particularly active in the brewing industry. Nomura financial holding dominated both the Pilsner Urquell Brewery and in the Nošovice Brewery through the IMP Finance investment company in the latter half of the 1990s [Zavadilová, 1998]. South Bohemia Breweries were dominated by the Českomoravská pozemková company, owned by František Chvalovský, an entrepreneur and the head of the Football Association [zdz, 1998]. Moravian-Silesian Breweries were also privatised by the voucher privatisation and their ownership structure remained relatively fragmented. The following five largest brewing companies were formed and gradually stabilised during the 1990s [Zíková, 1996]:

- Pilsner Urquell, with its brewery in Karlovy Vary belonging to the group;

- Radegast, along with the Nošovice, Most-Sedlec, and Velké Popovice breweries;

- Prague Breweries, which controlled the Staropramen, Braník, Holešovice, Vratislavice, and Ostravar breweries;

- Moravian-Silesian Breweries including the Litovel, Přerov, Hanušovice, and Opava breweries;

- South Bohemian Breweries with the Samson, Třeboň, and Protivín breweries. 
These five largest groups were complemented by three independent breweries: Budvar, Krušovice and Starobrno. The above-mentioned entities produced over 14 million hectolitres of beer in 1996, i.e., 76.8 \% of total production [Stellner \& Polanecký, 2016; Zemské noviny, 1997]. In terms of ownership, Budweiser Budvar held a special position because of unresolved litigation with the American brewer Anheuser-Busch and remained under state ownership despite investor interest. Krušovice and Starobrno were privately owned.

The major enterprises were relatively stable at the end of the millennium due to the size of their market shares and the strong investor entry to the market due to this financial background. The resulting ability to invest in new technologies further strengthened this position. However, the size of a group itself did not mean it was safe, as documented by the development of South Bohemian Breweries. These breweries failed to maintain their initial position following their ownership by IPB and, subsequently, the František Chvalovský group. South Bohemian Breweries signed a questionable contract with Pilsner Urquell at that time regarding joint distribution and lost more than half of its sales in just one year after jointly supplying pubs and restaurants [eko \& ČTK, 2000]. The output decreased from 1 million hl in 1997 to just $656,000 \mathrm{hl}$ in 1999 . This drop led to a significant redundancy in production capacity and can be considered to be the main cause of the resulting disintegration of the group when the Regent and Platan breweries were sold. As a result, South Bohemian Breweries has retained the Samson brewery since 2000 [eko \& ČTK, 2000; Stellner \& Polanecký, 2016].

The main interest of the major players was to gain maximum market share and the realisation of economies of scale in conjunction with investment into the latest technologies and the use of modern management approaches [Newberry, 1993; Green, 1999]. Additional investment in technology led to an increase in production capacity, which in turn, led to intensified competitive pressures with the limited ability of the market to absorb additional production [Newberry, 1993; Ptáčník, 1999]. The redundancy in production capacity at the time was estimated at 30\% [Murray, 1995] to 35\% [Zíková, 1996].

\subsubsection{Industry behaviour}

In addition to attractive large breweries, the state owned a considerable group primarily comprised of regional breweries with varying levels of competitiveness. The breweries were privatised in different ways, for example in the form of a public sale for small privatisations such as the breweries in Český Krumlov and Humpolec, or in a direct sale, such as the brewery in Pelhřimov [Stellner \& Polanecký, 2016]. The position of regional breweries came under threat from pressure from the large breweries, which with their ability to realise economies of scale, were able to invest in technology due to their strong distribution position [Green, 1999]. Their investments further increased the ability of big breweries to raise output and compete with lower prices. Simultaneously, the more successful marketing approach by the large breweries was evident and was again based on a sufficiency of resources [Green, 1999]. In this way, the major players were able to disrupt the previous dominance of the regional breweries in their respective regions. Moreover, the South Moravian breweries, which had been significantly historically oriented to the Slovak market due to their geographic location, suffered 
a significant loss of sales in the Slovak Republic after the split of the federation and the subsequent introduction of import tariffs by Slovakia. For some of these breweries, the Slovak market represented up to half of their production [Maukš, 1997]. For example, Antonín Kratochvíle, the CEO of the Czech Beer and Malt Association (ČSPS), openly suggested to Slovak officials that to create unjustified trade barriers may even be an abuse of licensing policy and relations in the former Customs Union between the Czech and the Slovak Republics [red, 1999]. Thirteen small breweries existed in South Moravia in the early 1990s. Due to the above-mentioned reasons, production ceased at breweries such as Břeclav, Uherský Ostroh, Brumov, Boskovice and Jarošov [Maukš, 1997].

Under these conditions, small and medium-sized breweries could compete on the market through product differentiation although only some of them used this at that time. An example of this strategy is the Bernard Brewery [Rocks, 1996]. Another option was to gain sales abroad, which met with mixed results because this approach is vulnerable to external conditions and market experience. For example, the introduction of the abovementioned import quotas to protect the target market may drastically change initially successful entries into new markets. The final option was the pursuit of success using a low-price strategy, which has been employed by the majority of medium-sized breweries. However, this strategy is usually unsuccessful because of the impossible objective of achieving significant economies of scale in an environment with extremely strong competition from large breweries plus a lack of resources to invest in new technologies.

This situation resulted in the gradual economic weakening of medium-sized breweries, which were subsequently purchased by major breweries and eventually closed down [Ptáčník, 1999]. The total concentration of the industry is illustrated through the numbers, where the 70 industrial breweries that operated in the Czech Republic in 1989 fell to 52 by the end of the 1990s [Ptáčník, 1999; red, 1999]. At the end of 1999, there were just 50 breweries, which belonged to 42 groups [Pšenička, 2001]. Almost onethird of the breweries and malthouses closed after 1990 and have since disappeared. This trend especially affected breweries under the influence of the largest breweries as they were no longer needed in terms of production capacity, for example, the breweries in Domažlice and Cheb that were closed by Pilsner Urquell and the Holešovice and Vratislavice breweries that were closed by the Prague Breweries [Ptáčník, 1999]. The eight largest Czech breweries held $80.6 \%$ of the beer market in 1999 [CSPS, 1999], while in 1992 a similar market share was covered by the eleven largest breweries [Newberry, 1993]. Pilsner Urquell made a clear attempt to dominate South Bohemian Breweries at the time [Boland, 1997]. Although this attempt was unsuccessful, it helped bring about the aforementioned weakening and subsequent disintegration of this group [eko \& ČTK, 2000].

Nomura became the focus of attention by managing the merger of Pilsner Urquell with Radegast, which ensured the group had a 44\% market share [ciz, 1999; Filla, 1999]. This merger became associated with the fear of the total destruction of competing brewers and was repeatedly challenged at the Czech Antimonopoly Office by the British brewer Bass PLC [Rocks, 1997]. IPB and Nomura advocated the merger by their efforts to improve the situation on foreign markets, where current Czech companies were seen as economically weak [Madden, 1997; Rocks, 1997]. Although beer production is relatively inexpensive, the more expensive the distribution becomes then the more economies of 
scale may be realised, which is considered to be another reason for seeking maximum market share [Green, 1999]. Fears of the change in the competitive environment after the surprising acceptance of this merger by the Czech Antimonopoly Office [Anderson, 1999] were not confirmed by subsequent developments [zdz, 2000]. On the contrary, there was a significant change in strategy that came with the new owner of the group, South African Breweries (SAB). SAB took this acquisition as a useful entry onto the Eastern European market and began to stabilise the economic results by a gradual retreat from the price war [Anderson \& Willman, 1999].

A systematic increase in the importance of microbreweries is a trend that goes against the concentration of the industry. However, due to the small number and size of their total output, their contribution to the overall figures is negligible and is the prevailing influence of the overall decline in the output of the small and medium-sized breweries [Pírek \& Rysková, 1997]. The growth of small breweries is also supported by tax legislation by lowering the tax rate on the production of breweries producing less than $200,000 \mathrm{hl}$ per year [Zákon, 2003]. This support provides partial protection to small breweries against pressure from major competitors who use direct pressure on small customers and offer short-term financial benefits to restaurant and pub owners in exchange for a commitment to exclusively take their products to gain market share [Maukš, 1997; Motejlek, 1998; Pitlík, 1996].

\subsubsection{Strategy}

The latter half of the 1990s was dominated by a price war. Stanislav Bernard [Maukš, 1997] and the Director of the Primátor Brewery in Náchod, Josef Hlavatý [Filla, 1999] have directly stated that this war primarily raged among the major breweries as the market share increased their market value although it decimated all the other breweries [Green, 1999]. The consequence, and in part the aim, was the above-mentioned total concentration of the industry. The result of this war was the relatively slow increase in the nominal prices of production in comparison with the overall growth of inflation [Pitlík, 1996], where the real price level remained very low compared to other countries. This can be illustrated by the ratio between the price of a bottle of draft beer and the average wage. It was possible to buy 1,269 bottles of draft beer with one average salary in 1990 and 1,774 bottles in 2000 [Kratochvíle, 2005].

This situation was also influenced by several factors. Low brand loyalty [Cook, 1999] was emphasised by the entry of the retail chains, which used their business strength to shape the market environment and contribute to the price competition [Beránek, 1997] while helping to facilitate changes in customer brand loyalty. A key role was also played by the beliefs of the main actors, for example, the CEO of Prague Breweries, Stanislav Procházka, who believed that the majority of customers did not have particularly "deep pockets" and any price increase would mean an outflow of buyers [Fiedlerová, 1996]. Another limiting factor on the customer side, and mentioned in other sources, emphasised the negative effect of some of the actual consequences of economic transformation, such as the increase in unemployment, the decline in the purchasing power of the population, and an overall decline in the certainty of future revenue, which led to restrictions on immediate consumption [red, 1999]. In this context, a gradual shift in consumption from pubs to cheaper bottled beer from supermarkets is mentioned [Boland, 1997], although 
the percentage of bottled beer produced from the total production does not validate this theory [Kratochvíle, 2005].

The market entry and the initial success of cheap low-degree beers, such as Primus, Klasik, and others was a result of these trends and were also exacerbated by them. These beers were sold at extremely low prices that were considered by competitors to be dumping prices. The majority of customers showed a greater sensitivity to price than quality at this time, which greatly limited potential forms of competition. Although the explanation for such behaviour may appear to be that customers reflected the price competition by the vast majority of producers, it was more likely it was a response to the overall economic situation in the country and the manifestation of momentum in the thinking of customers raised under the socialist economy of scarcity.

The manufacturers responded to this situation by optimising production costs and due to the excess capacity even reduced the margins [Boland, 1997; Rocks, 1997]. Renewed growth in margins began to be observed in 1999 and 2000 [Veselská, 2005]. This conclusion is consistent with the gradual change in pricing policy, which began to show a gradual increase in prices at the end of 1996 when Pilsner Urquell increased theirs by $10 \%$. This increase was higher than the inflation rate although it still did not reach the accumulated cost increases of previous years [Boland, 1997]. Significant changes in this direction were recorded on the market throughout 2000 with the Starobrno Brewery making the first significant price increase. A positive step was also taken with the stabilisation of the ownership structure of Pilsner Urquell when the brewing giant SAB became a key owner and replaced the Nomura financial holding [Anderson \& Willman, 1999]. The gradual increase in microbreweries gradually began to fill the gap in the market supply previously caused by the weakening of regional breweries. These companies mostly used a focal differentiation strategy, although some tried to follow a low-cost strategy, which came to be regarded as a strategic mistake at the end of the decade as they had previously been weakened by the price war.

On the contrary, the ability to produce at low costs at the same time had a positive effect on exports, which occurred in a decade that had then become relatively stable through the dominance of the largest breweries together with Budvar. At the same time, the export activity of most other major breweries was evident and led to a slow decrease in Budvar's share of total exports, which gradually dropped below $30 \%$. In terms of export volume, Pilsner Urquell and the Prague Breweries followed Budvar. Pilsner Urquell experienced a temporary decline in exports in the first half of the 1990s, which can be attributed to changes in management associated with the consolidation of the ownership structure following voucher privatisation [Murray, 1995]. Medium-sized and small breweries entered into this domain rather irregularly with significant fluctuations although they were not particularly relevant in terms of the total volume of exported beer. The export share of the ten largest breweries was around $90 \%$ with a tendency towards slow growth in the long-term outlook [Pírek \& Rysková, 1997]. The process followed the fluctuations in total beer production [Pírek \& Rysková, 1997]. Nevertheless, from the perspective of the decade, a slight decrease is apparent while the same applies to beer exports, as shown in Figure 2. 


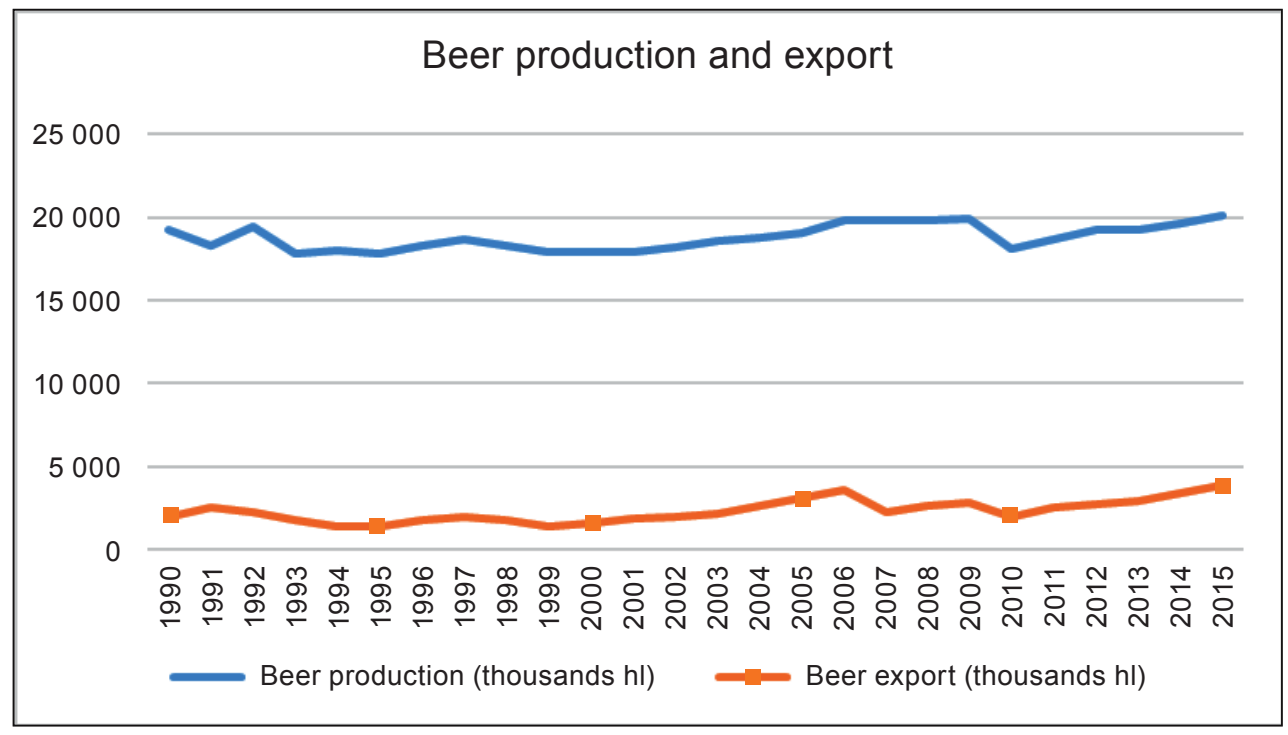

Source: authors' own calculations

\subsubsection{The advent of special beers}

Throughout the 1990s, the popularity of light beer - especially $10 \%$ OWE - prevailed, which was complemented by a $30 \%$ share of $11 \%$ and $12 \%$ OWE beer. Stronger beer consumption did not exceed one percent of the total consumption [Pírek \& Rysková, 1997]. Although special beers had gained a stable market position and a customer segment was willing to pay a higher price, the share in total production remained low until the end of the 1990s; see Table 1. This is in line with the opinion of Daniel Váša, the brewer at the Town Brewery in Nová Paka, and the director of the Jihlava brewery, Jan Kylberger [ciz, 1999]. Despite this, incorporating special beers into the product portfolio became a matter of prestige for small breweries and was used to highlight their visibility on the local market. The importance of special beers to individual breweries varied considerably. In the case of large breweries, such as Pilsner Urquell, the percentage was still relatively low although in the case of the Bernard Brewery, for example, a special beer accounted for $7 \%$ of total sales in 1999 and continued to gradually increase. The Bernard Brewery clearly used a differentiation strategy [ciz, 2000]. One reason for the smaller percentage of special beers by the major breweries may have been the economic pressure to fully utilise the newly upgraded high-capacity technology. Even so, there were visibly major changes in the thinking of the large breweries. "The whole beer industry in the Czech Republic is under reconstruction," said Mario Junek, the Financial Director at Pilsner Urquell. "We've changed from production-centred factories to trade-oriented companies" [Rocks, 1996].

Breweries reacted to price wars in various ways. A specific example of the approach to product portfolio is the Svijany Brewery, which was closed due to overcapacity within the Prague Breweries concern. The new owner successfully used a temporary weakening of competitive pressures in the region based on the closure of the brewery in Vratislavice 
[Pšenička, 2001]. This time out enabled the economy of the brewery to stabilise and gradually refocus production on higher-margin products, such as stronger and special beers, from 1998. The brewery also sought to differentiate its product [SVIJANY, 2016]. An example of a similar attempt to compete through differentiation is the Cerná Hora brewery [Maukš, 1997]. Special beers were not the exclusive domain of small breweries. For instance, Staropramen from Prague Breweries has been successful among the larger players in this segment [ciz, 2000]. It appears that despite its continual domination of cheaper draft beer consumers, the demand for so-called super cheap beer began to weaken at the end of the decade [red, 1999]. The growing interest in flavourful and interesting special beers was confirmed by the Sales Director of the Lobkowicz Brewery, Petr Peniaštek [Barták, 2000]. This explained the brewery's improved economic results in 1999 as it transitioned from cheap to special beers, which brought both a reduction in overall production and an economic upturn. Both Stanislav Bernard and the brewer of the Herold brewery in Březnice, František Pinkava, explained this increased customer interest as the result of the trend for moving to quality and consistently keeping to tradition [Pšenička, 2001].

A large number of breweries reported an improvement in their economic situation at the end of the 1990s despite a slight decrease in the total production. According to Ivo Štork, the director of the South Moravian brewery Černá Hora, this improvement was based on growing customer demand for better products, a weakening in competitive pressures, and the price war by the large breweries. The large breweries also began to increasingly emphasise quality and special offers. This also indicated an increase in profit for Pilsner Urquell in 1999, while production declined by about $6 \%$. Vladimír Peřina, the CEO of Pilsner Urquell, directly stated that Primus beer had already fulfilled its historic role once the brewery opened the door to most supermarkets so it was no longer needed [P̌̌enička, 2001]. There are obvious benefits to large groups as they can simultaneously use different strategies for different market segments.

\subsubsection{The conclusion to the decade}

The privatisation and entry of foreign capital can be viewed from different perspectives. A positive factor was the increase in the competitiveness of the large breweries based on the technological leap made possible by capital injections. However, the next concentration of the industry was due to the result of this change and from the aggressive competitive policy of the large breweries. Large breweries used their market share and especially their economic power to pressure the transformation of the restaurant and pub sector, where in exchange for material assistance they required the commitment to exclusively take their products [Maukš, 1997; Motejlek, 1998; Pitlík, 1996]. This trade policy was particularly viewed by small breweries to be negative [ciz, 1999]. Most of the decade was characterised by the price war that resulted from the fight for market share and was enforced by the overall economic situation in the country coupled with the momentum in the thinking of customers raised under the socialist economy of scarcity. On the other hand, it is obvious that some small breweries were able to survive in this period and even strengthen their position in this situation while they were able to learn and focus on effective marketing and quality products. These included, for example, the previously mentioned Bernard in Humpolec, Hostan in Znojmo, Janáček in Uherský Ostroh, the Town Brewery in Havlíčkův Brod, Svijany, and Náchod. 


\subsection{The New Millennium}

Industry behaviour changed little in the new millennium with low-price wars and the continuation of the growth in beer production. Breweries continued to go bankrupt due to price wars and other competitive measures [Kňourek \& Mrázek, 2002; Žufan \& Pyšný, 2005] while concentration continued [Bohuněk, 2002], together with the strengthening of the major breweries and weakening of medium-sized and small breweries [Smrčka, 2003]. However, this was a global trend observed during the 1990s [Beránek, 1997], which arrived in the Czech Republic with a delay due to the gradual liberalisation of the market [Pyšný \& Žufan, 2006]. This gave rise to brewing groups, which unlike in previous years, did not respect past geographical distribution. There were over 70 breweries in the Czech Republic in 1990 and much debate as to whether small breweries could withstand the pressure from large multinational companies [Junek, 2004; Korbel, 2003; Mrázek, 2004]. It transpired that although many small breweries survived, medium-sized businesses with a production of 400,000 hectolitres were wound up. "Market turbulence has vanished and the market situation is now stable," said the chairman of the Czech Beer and Malt Association, Jan Veselý [Kaláb, 2005]. There were no medium-sized breweries in the Czech Republic in 2004, only small and large ones. In total, there were 38 companies of which 30 produced less than 200,000 hectolitres per year. The remaining 18 breweries were owned by 7 different groups, among them large enterprises with annual sales of over 600,000 hectolitres while the number of microbreweries continued to rapidly rise - in 2004, numbers increased from 30 or 40 [Kaláb, 2005] to an estimated 69 in 2008 and 93 by 2010. Our calculation shows even higher figures; see Table 1. However, the total production of all the microbreweries in the Czech Republic was still negligible [Maier \& Fabianova, 2011; Zuntych, 2007a] due to their local distribution.

Exports of Czech beer grew in connection with the country's entry into the Customs Union (the Czech Republic joined the EU in 2004), and were dominated by Budvar, Pilsner Urquell, and the other large breweries [Datamonitor, 2005; 2006; Kaláb \& Mařík, 2004; Datamonitor, 2008]. Although dominated by the large breweries, small and medium-sized breweries were also successful in exporting to EU countries [Kaláb, 2005; PP Agency, 2007]. As a result of the Customs Union, imports of foreign beer grew in an attempt to penetrate the Czech market. Foreign investment and international owners proved to be good for beer exports [Hergetová, 2015b; Janda \& Mikolasek, 2011; Pulec, 2016].

The most significant case is the entrance of one of the world's largest breweries to the Czech Republic. In order to strengthen its position in Central Europe, the Dutch company Heineken merged with the Austrian group BBAG, the owner of the Starobrno Brewery and the fifth largest brewery in the Czech Republic. This represented another major brand after SABMiller and Interbrew [Kabeláčová, 2004]. The purchases of other major breweries continued when Heineken bought Krušovice in 2008 and later the tenth largest producer the Drinks Union, which operated several breweries in Northern Bohemia although some of those breweries were closed. Thus, Heineken affirmed its market position as the third largest group [Francová, 2010].

The entry of foreign capital, as well as the expansion of the portfolio, increasingly led to the use of new brewing technologies. This technological change had significant 
implications for the market in several aspects. Using cylindrical-conical tanks (CCT) significantly reduced the time of lagering [Budínský \& Zázvorka, 2008] and therefore enabled a sharp increase in production thereby increasing the total capacity of the brewery. This enabled cost reductions per unit of beer, leading to a low-cost strategy and price war between the large breweries and the medium-sized breweries [Pyšný \& Žufan, 2006] as previously mentioned. Medium-sized breweries could not afford large investment into new technologies so their unit costs remained high. This began in the late 1990s [Filla, 1999] and further intensified during the first decade of the new century. To maintain competitiveness, medium-sized breweries needed to reduce the price of their products [Truhlička, 2002], thus losing the resources for investment and advertising that would have developed the company. The second aspect of using advanced technology was reducing the differences among individual batches [Böhm, 2008]. This, together with the use of $\mathrm{CO}_{2}$, pasteurisation and filtration significantly eliminated risks and extended the lifespan, especially for bottled beer. This helped the large breweries penetrate the bottled beer market through the large supermarket and hypermarket chains, which at the beginning of the decade underwent intensive development and became a crucial link in the distribution chain. Small breweries using traditional production technologies could not provide the same long shelf life of the product and also failed to meet the price demands of the retail chains [Datamonitor, 2008; Žufan \& Pyšný, 2005; Datamonitor, 2009; 2007]. On the contrary, the large breweries penetrated the market due to low production costs caused by changing technology. In combination with the pressure of competition from supermarkets, bottled beer became considerably cheaper (see Table 2) than beer in restaurants and pubs (where the average prices were 16.20 CZK in 2005 and 21.20 CZK in 2010) in addition to having an excellent distribution network.

Table 2 | Average prices of bottled beer in CZK per $0.5 \mathrm{I}$

\begin{tabular}{|l|c|c|c|c|c|c|c|c|c|c|}
\hline & $\mathbf{2 0 0 1}$ & $\mathbf{2 0 0 2}$ & $\mathbf{2 0 0 3}$ & $\mathbf{2 0 0 4}$ & $\mathbf{2 0 0 5}$ & $\mathbf{2 0 0 6}$ & $\mathbf{2 0 0 7}$ & $\mathbf{2 0 0 8}$ & $\mathbf{2 0 0 9}$ & $\mathbf{2 0 1 0}$ \\
\hline January & 7.69 & 7.91 & 8.54 & 8.63 & 8.65 & 8.47 & 8.36 & 8.93 & 9.30 & 9.84 \\
\hline February & 7.67 & 7.93 & 8.56 & 8.62 & 8.67 & 8.47 & 8.36 & 8.94 & 9.12 & 9.99 \\
\hline March & 7.71 & 7.93 & 8.57 & 8.60 & 8.68 & 8.40 & 8.33 & 8.81 & 9.11 & 9.92 \\
\hline April & 7.79 & 8.32 & 8.64 & 8.66 & 8.47 & 8.42 & 8.39 & 8.89 & 9.25 & 9.98 \\
\hline May & 7.85 & 8.42 & 8.67 & 8.57 & 8.42 & 8.47 & 8.52 & 8.87 & 9.19 & 9.91 \\
\hline June & 7.82 & 8.43 & 8.52 & 8.52 & 8.47 & 8.37 & 8.53 & 8.93 & 9.12 & 9.49 \\
\hline July & 7.80 & 7.41 & 8.62 & 8.48 & 8.43 & 8.41 & 8.60 & 9.06 & 9.18 & 10.03 \\
\hline August & 7.82 & 8.44 & 8.59 & 8.50 & 8.39 & 8.35 & 8.51 & 8.94 & 9.15 & 9.72 \\
\hline September & 7.81 & 8.44 & 8.61 & 8.53 & 8.35 & 8.35 & 8.54 & 9.05 & 9.24 & 9.84 \\
\hline October & 7.82 & 8.34 & 8.54 & 8.52 & 8.38 & 8.38 & 8.55 & 9.07 & 9.24 & 9.77 \\
\hline November & 7.81 & 8.33 & 8.59 & 8.49 & 8.39 & 8.37 & 8.71 & 9.11 & 9.19 & 9.88 \\
\hline December & 7.79 & 8.41 & 8.60 & 8.48 & 8.41 & 8.32 & 8.74 & 9.13 & 9.10 & 10.05 \\
\hline
\end{tabular}

Source: [CZSO, 2016] 
Both these aspects compelled small and medium-sized breweries to reduce excessively priced items. Long-term price subsidies by breweries resulted in economic problems for small breweries, which led to bankruptcy, selling the business, or the entry of a strong investor [Mrázek, 2004; Ptáčník, 1999]. The result was the gradual disappearance of medium-sized breweries; 26 breweries ceased production between 1990-2006 [Králová, 2010a].

On the other hand, due to changes in technology, the taste worsened and the differences between different brands lessened according to many customers. This resulted in a reduction of customer loyalty, as most beers "started to taste the same." At this time, there was talk about the unification of Czech beers as the large breweries began to produce only "Euro beer" [Budínský \& Zázvorka, 2008]. Although Euro beer is not an official brewery term it is used in connection with a less distinctive flavour of beer compared to the original technology, although this is a very subjective perception. It is often used as a synonym for cheap beer or a retail chain beer brand, which can be made in any brewery [Vacl, 2008]. This unification, together with demographic trends and changes in consumer lifestyles [Truhlička, 2002] contributed to changing the drinking habits of society. These habits began to shift from quantity to quality over the decade, i.e., to the consumption of lower amounts, but with better quality.

To survive the existing price pressure exerted by the large breweries, the smaller breweries had to change their production and sales strategies. By the end of the 1990s, they had already begun to create products that did not directly compete against the mainstream and cheaper beers produced by the major breweries [ciz, 2000]. At this point, the use of a typical differentiation strategy or a focal differentiation strategy can be discussed. At the beginning of the new decade, products based on this strategy had become more frequent [Klos \& Macků, 2002]. The customer, or the customer segment, no longer wanted the cheapest product, but rather a better quality product for which they were willing to pay [Zuntych, 2007a]. These changes developed the scope for a wider application of differentiation strategies, which were more frequently applied among the medium-sized and small breweries from 2004 to 2006, a period associated with the wider development of microbreweries [Kaláb, 2005]. The foundation of microbreweries also contributed to the fact that technology for small-scale beer production scale became affordable, and its price decreased to the lower units of a million [MF Dnes, 2006]. In the case of local microbreweries, in addition to the specific flavour that differentiated them from the Euro beers, the image of the local character played an important role. This image became more attractive to customers than the "industrial brewery" [Kaláb, 2005]. The strategy of differentiation or focus differentiation was targeted on a narrow geographical segment and became a key method in the competition between small and medium-sized and large industrial breweries [ciz, 2000; Všetečková, 2006].

To reduce the risk of the imminent decline of draft beer, large breweries responded in two ways. Firstly, they strengthened their already strong position in the bottled (packaged) beer segment [Zuntych, 2007b]. Packaging design change arose as an effective tool, and more original and eye-catching packaging was used. This was reflected in increased sales of bottled beer and within two years, most of the large breweries started to use new bottles. Small breweries were unable to respond to the change because of a lack of capital. This was combined with a legislative measure for reusing bottles [Jilemnický, 2006]. Secondly, a new distribution concept began to gradually appear, which had been 
created by most of the major breweries in the draft beer segment in 2006-2008. Breweries opened "brand pubs", which are owned by individual breweries or run as a franchise and differ by the exclusivity of the beer sold, e.g., beer that is not sold elsewhere, or a higher standard of service. Pilsner Urquell, Staropramen, Budvar, and Kozel gradually spread the concept. The Velké Popovice brewery, in particular, developed a concept called "Kozlovna" and the Pilsner Urquell brewery developed a concept called a "Pilsner Urquell Original Restaurant", which was considered to be the most successful. It was characterised by a unique design and the drafting of beer straight from the tank. Beer in a tank passes through a filtering process instead of pasteurisation and as such should have a more specific taste. It was viewed as a step towards differentiation and other large breweries followed a similar path [Kuciel, 2008]. This created a direct alternative to the increasingly popular mini-breweries and restaurants with their own brewery, whose number approached 100 by the end of the decade [Petr, 2009].

During the first decade of the new millennium, the emphasis on the communication and promotion mix significantly increased, reflecting the conservatism and national pride of Czech customers [Short, 2008]. Therefore, it came as no surprise that after acquiring Starobrno, there was no attempt to rebrand the company and Heineken kept a local and patriotic approach. Krušovice also emphasised their historical origins and tradition as one of the oldest major breweries. This communication mix, however, is similar to most breweries: Radegast markets itself as a Silesian, North Moravian brand; Budweiser Budvar naturally accentuates its South Bohemian origin; Starobrno highlights its position and origin in Moravia; Pilsner Urquell as the largest and one of the most exported brands shows its origins as Bohemian or Pilsner [Šmejkal, 2004]. Large breweries try to communicate with customers primarily through mass media - Alexei Bechtin characterised the communications of the Pilsen group in 2004 as follows, "Most often we use television. Television makes over $50 \%$ of all communication, the rest represents other media (print, radio, outdoor), which are represented in much the same proportion." The share of ATL and BTL is balanced and varies among individual brands, making the total percentage of the portfolio difficult to determine [Šmejkal, 2004]. In contrast, the smaller breweries used alternative methods, i.e., a greater focus on local tourism and cooperation with local authorities. Examples are the three-star Hotel U Sládka, which opened at the Chodovar brewery and the organisation of various events, such the Open Cellars Day at the Měštanský Brewery in Polička, brewer fairs and celebrations in Černá Hora and Strakonice, steam train drives around the Chodovar and Nymburk breweries, etc. [Drozdová, 2015].

\subsection{0 to date}

The Czech market structure continued the concentration from the previous decade. The market was divided among the three main players (SABMiller, Anheuser-Busch InBev and Heineken) in 2010 [Datamonitor, 2011] along with the Molson Coors Brewing Company, which was also active in the Czech Republic [Pulec, 2016]. The strongest player nowadays is SabMiller, followed by Pivovary Staropramen owned by Molson Coors. Heineken is the third strongest group followed by the national brewery Budweiser Budvar. The Pivovary Lobkowicz Group and Moravian-Silesian Breweries are also major players in the Czech brewing industry [PP Agency, 2015; Šámal, 2016; Šámal \& Falge, 2015; Šenk 
\& Hrdličková, 2014]. These groups associate 19 breweries in the Czech Republic; the remainder of the market was comprised of 29 independent industrial breweries and around 300 micro-breweries at the end of 2015 [MACR, 2015; PP Agency, 2015]. The majority of the Czech brewing industry (based on market volume) is owned and financed by foreign investors, respectively all strategic groups. Anheuser-Busch InBev is Belgian, Heineken is Dutch, and the Lobkowitz Group is partly owned by Chinese investors and a company based in Cyprus. It is not only foreign investors that own the large brewing groups - some smaller breweries are also financed from abroad, for example by Chinese or Belgian (Bernard brewery) owners [Kain, 2015; Pulec, 2016]. Nevertheless, the ownership structure is not easy to identify. Table 3 shows the ownership of the largest breweries according to production.

Table 3 | Ownership of breweries

\begin{tabular}{|c|c|c|c|}
\hline Brewery & Region & Owner & Strategic group \\
\hline Pivovar Staropramen & Prague & $\begin{array}{l}\text { Pivovary Staropramen } \\
\text { s. r. o. }\end{array}$ & $\begin{array}{l}\text { Molson Coors Central } \\
\text { Europe }\end{array}$ \\
\hline $\begin{array}{l}\text { Budějovický } \\
\text { měšt’anský pivovar }\end{array}$ & South Bohemia & $\begin{array}{l}\text { Anheuser-Busch } \\
\text { InBev }\end{array}$ & $\begin{array}{l}\text { Anheuser-Busch } \\
\text { InBev }\end{array}$ \\
\hline $\begin{array}{l}\text { Pivovar Budějovický } \\
\text { Budvar }\end{array}$ & South Bohemia & Czech Republic & \\
\hline $\begin{array}{l}\text { Městský pivovar } \\
\text { Platan }\end{array}$ & South Bohemia & $\begin{array}{l}\text { Pivovary Lobkowicz } \\
\text { Group }\end{array}$ & $\begin{array}{l}\text { Pivovary Lobkowicz } \\
\text { Group }\end{array}$ \\
\hline Pivovar Černá Hora & South Bohemia & $\begin{array}{l}\text { Pivovar Černá Hora } \\
\text { a. s. }\end{array}$ & $\begin{array}{l}\text { Pivovary Lobkowicz } \\
\text { Group }\end{array}$ \\
\hline Pivovar Starobrno & South Bohemia & $\begin{array}{l}\text { Starobrno a. s. } \\
\text { (majority owner } \\
\text { Heineken) }\end{array}$ & Heineken \\
\hline $\begin{array}{l}\text { Rodinný pivovar } \\
\text { Bernard }\end{array}$ & Vysočina & $\begin{array}{l}\text { Rodinný pivovar } \\
\text { Bernard, a. s. }\end{array}$ & \\
\hline Pivovar Jihlava & Vysočina & Pivovar Jihlava, a. s. & $\begin{array}{l}\text { Pivovary Lobkowicz } \\
\text { Group }\end{array}$ \\
\hline $\begin{array}{l}\text { Pivovar Primátor, } \\
\text { Náchod }\end{array}$ & Hradec Králové & LIF a. s. (Liberec) & \\
\hline Pivovar Svijany & Liberec & Pivovar Svijany a. s. & \\
\hline Pivovar Ostravar & Moravian-Silesian & $\begin{array}{l}\text { Pivovary Staropramen } \\
\text { s. r. o. }\end{array}$ & $\begin{array}{l}\text { Molson Coors Central } \\
\text { Europe }\end{array}$ \\
\hline Pivovar Radegast & Moravian-Silesian & $\begin{array}{l}\text { Plzeňský Prazdroj } \\
\text { a. s. }\end{array}$ & SABMiller \\
\hline Pivovar Holba & Olomouc & Pivovar Holba, a. s. & PMS, a. s. \\
\hline Pivovar Litovel & Olomouc & Pivovar Litovel a. s. & PMS, a. s. \\
\hline
\end{tabular}


Continued from page 20

\begin{tabular}{|c|c|c|c|}
\hline Brewery & Region & Owner & Strategic group \\
\hline Pivovar Zubr & Olomouc & Pivovar Zubr a. s. & PMS, a. s. \\
\hline $\begin{array}{l}\text { Pivovar Plzeňský } \\
\text { Prazdroj }\end{array}$ & PIzeň & $\begin{array}{l}\text { Plzeňský Prazdroj } \\
\text { a. s. }\end{array}$ & SABMiller \\
\hline Pivovar Gambrinus & Plzeň & $\begin{array}{l}\text { Plzeňský Prazdroj } \\
\text { a. s. }\end{array}$ & SABMiller \\
\hline $\begin{array}{l}\text { Královský pivovar } \\
\text { Krušovice }\end{array}$ & Central Bohemian & $\begin{array}{l}\text { Královský pivovar } \\
\text { Krušovice a. s. }\end{array}$ & Heineken \\
\hline Pivovar Nymburk & Central Bohemian & $\begin{array}{l}\text { Pivovar Nymburk spol. } \\
\text { s. r. o. }\end{array}$ & \\
\hline $\begin{array}{l}\text { Pivovar Velké } \\
\text { Popovice }\end{array}$ & Central Bohemian & $\begin{array}{l}\text { Plzeňský Prazdroj } \\
\text { a. s. }\end{array}$ & SABMiller \\
\hline $\begin{array}{l}\text { Pivovar Vysoký } \\
\text { Chlumec }\end{array}$ & Central Bohemian & $\begin{array}{l}\text { Pivovary Lobkowicz } \\
\text { Group }\end{array}$ & $\begin{array}{l}\text { Pivovary Lobkowicz } \\
\text { Group }\end{array}$ \\
\hline Pivovar Velké Březno & Ústí nad Labem & Heineken & Heineken \\
\hline
\end{tabular}

Source: [MJCR, 2016]

Figure 3 | Market structure by owners

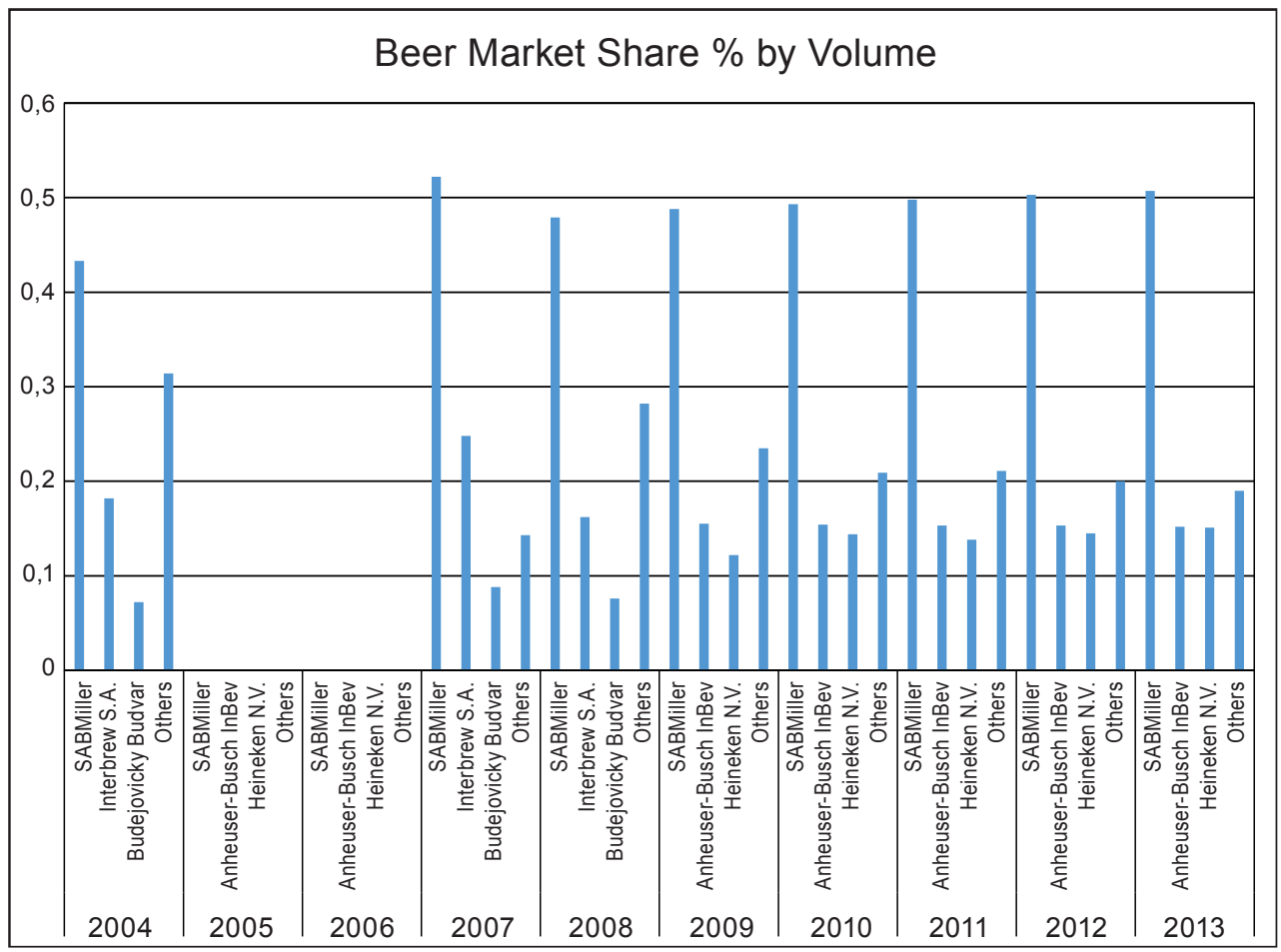

Source: [Datamonitor, 2005-2013; Marketline, 2014] 
Figure 3 shows the market shares of the largest brewing groups in the Czech Republic, which is longitudinally dominated by the SABMiller group. Overall, the fight to gain market share through brewery or whole group acquisitions are known throughout history and have also proved to be useful acquisitions [Bouc, 2011b; Janda \& Mikolasek, 2011; Lavička, 2012; Petr, 2012a; PP Agency, 2015; Prchal, 2012; Procházková, 2010]. Nevertheless, in 2015 when change should have dominated, the focus was on the merger of SABMiller with its main competitor - AB InBev [Hergetová, 2015a; Lavička, 2015; Sedlák, 2015]. The reason for the merger was to acquire the world's largest market share and the well-known Pilsner Urquell brand [Hergetová, 2015a; Lavička, 2015].

\subsubsection{The economic crisis and industry behaviour}

The global economic crisis had a highly negative effect both on the overall economy and the brewing industry. The Czech Government reacted to the crisis by increasing the beer consumption tax in 2010. The taxation of beer is regulated by Act No. 353/2003 Coll. [Zákon, 2003] and a Government Resolution cut the tax from 24 CZK 24 to 32 CZK per hl causing consumption to decrease once again [MACR, 2014; Tůma, 2011] due to raising the price of 12 degree beer (premium beer) by up to CZK 1 [Adamčiková \& Königová, 2011; Drozdová, 2015; Procházková, 2010]. Light and moderate drinkers reduced their consumption but heavy drinkers did not accept the higher prices [Maier, 2012]. This situation proved difficult for the breweries. The whole industry faced a lack of demand and the market became oversaturated [Bouc, 2011a; Králová, 2010b]. Several breweries reacted by lowering the quality at the same price [Havel, 2011]. This led to efforts to reduce taxes in 2010 [Ptáčník, 2010] and 2014 [Sedláčková, 2014; Štrunc, 2014]. The resolution referred to at the beginning of this paragraph proved useful for smaller breweries (no more than $200,000 \mathrm{hl}$ per year) that have tax allowances. This appears to have been a positive consequence of the diversification of the Czech beer market by microbreweries [Hergetová, 2015b; Morávek, 2013]. Although the overall effect on the Czech brewing industry was negative [Adamčiková \& Königová, 2011; Havel, 2011], these efforts have been unsuccessful and the tax has remained at the same level.

The global economic crisis was reflected in a drop in beer consumption in 2009, and Czech breweries were pressed to reduce beer production in 2010 and look for other ways to survive. Overall consumption rapidly plummeted from 153 litres per inhabitant in 2009 to 143 in 2010 [Šámal, 2016]. This number briefly improved in 2012 with consumption reaching 146, only to fall to 143 in 2015 . Consumption appears to have been at the same level since 2010 although production is now increasing due to increasing exports [PP Agency, 2015]. Breweries have started to focus on the export market [Šenk \& Hrdličková, 2014], which is depicted in Table 1. The volume of exported beer in 2015 was twice as high as in 2010 [Š́mal, 2016]. Exports were successful due to the reputation and the trademark of Czech beer (Database of Origin \& Registration). The growth in exports can be observed for large breweries such as Budweiser Budvar and Pilsner Urquell as well as smaller breweries such as Bakalár in Rakovník, the Pardubice Brewery and various others [Bouc, 2011a; ČTK, 2012a; Economia \& Hospodářské noviny, 2013; Kain, 2015; Kvapil, 2015; Morávek, 2013; Petr, 2013b; PP Agency, 2015]. Czech beer is in demand throughout the whole world and breweries are exporting to 25 EU and 72 other countries [Š́mal, 
2016]. The majority of exported production is going to neighbouring countries - Slovakia, Germany and Poland [MACR, 2015; PP Agency, 2013; Šámal, 2016]. Breweries' efforts are mostly focused on the export of premium and special beers boosted by the Czech trademark [Šámal \& Falge, 2015; Šenk \& Hrdličková, 2014].

The economic crisis caused both a decrease in consumption and a diversification of the beer portfolio with the export-oriented breweries beginning to produce premium beers in demand and special beers. Shandies (beer mixes) and non-alcoholic beers gained a foothold in the market through their popularity with young people and women [Bouc, 2011a; Hrdličková \& Poljakov, 2015; PP Agency, 2013]. A large group of consumers became interested in premium beers and special beers rather than light beers [MACR, 2015; Morávek, 2013]. On the other hand, there were still consumers who preferred cheap beer - heavy drinkers and those on low incomes [Bouc, 2011a]. Figure 4 shows the development of beer consumption according to the type of beer. Special beers have emerged in the last five years [Veselý, 2011] and these are brewed by both microbreweries and large big breweries. Breweries frequently diversify their portfolio with non-alcoholic beers or sweet beers (lemonade-mixed beers) [Datamonitor, 2013; MarketLine, 2013; 2014; Datamonitor, 2011; MACR, 2013; Morávek, 2013; Petr, 2009; Vinopal, 2014]. Nowadays, many consumers are inclined towards a wide-ranging portfolio of beers, which has rapidly changed from the 1990s, when unified beers were preferred. Successful craft breweries should have all four types of beer in their portfolio: premium and special beers, beer mixes, and non-alcoholic beers [Dorčáková, 2015; Paloncy, 2013].

Figure 4 | Beer consumption $\%$, by type of beer

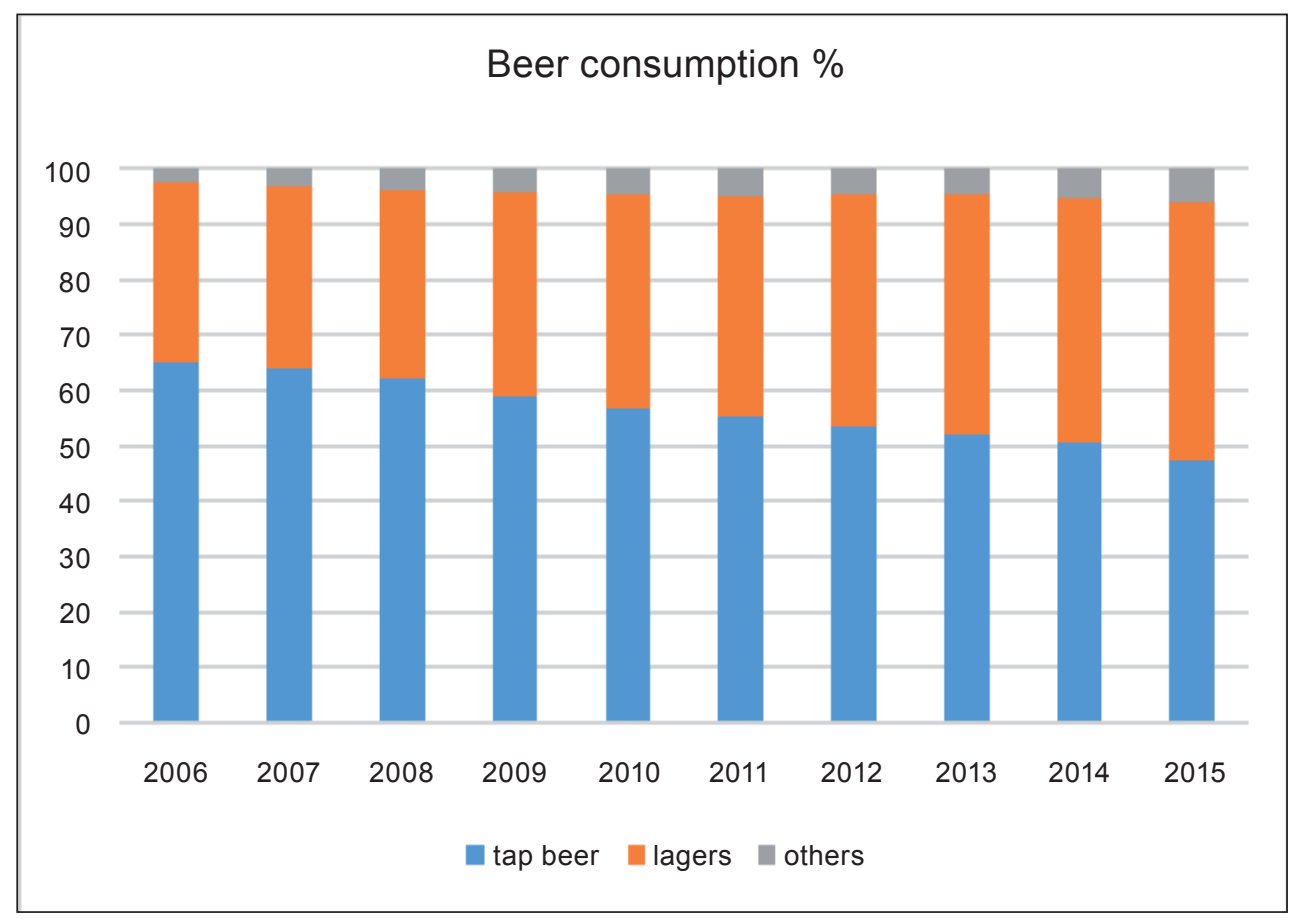

Source: authors' own calculations 
The first and most interesting group is premium and special beers. These beers are stronger than light beers, usually at $12 \%$ or more OWE [Bouc, 2011a; 2011b]. Special event beers that are produced for special occasions such as Easter, St. Patrick's Day and Christmas or beer from "the first hops" are the most popular [Morávek, 2013]. This inspiration from abroad was first adopted by the microbreweries [Klepetko, 2015; Němec, 2014], and later by the larger breweries as a response to the microbrewery revolution [ČTK, 2012b; Janouš, 2016; Petř́ícek, 2016; Tůma, 2011]. However, the majority of special beers are still produced by microbreweries [Petr, 2009; Sůra, 2015b]. They built their strategy on consumer preferences for quality and stronger beers, which are perceived to be higher quality. These customers drink less beer per evening but enjoy high-quality beer [MACR, 2015]. Unfiltered beer is perceived as a tradition; nevertheless, the current market offers numerous flavours - cherry, blackberry, and nettles - although wheat beers are the most popular [MACR, 2015; Pike, 2010]. The production of special beers is also connected to local patriotism, historical heritage, and beer tourism [šmu \& hni, 2005]. Those breweries producing special beers focus on demanding customers.

The opposite group of customers are those who are price-sensitive. Cheap beer is targeted at low-income consumers and is usually referred to as Eurobeer [Klepetko, 2015]. This type of beer is produced on a low-cost basis with a unified sweet taste and a lower hop content [Klepetko, 2015; Řeboun, 2013]. Breweries forced into low-cost production usually brew strong beer (for example 17 degree) and then adulterate it to the required light (10 degree) beer [Řeboun, 2013], thus reducing production costs. This negatively impacts the quality of the beer and the reputation of the Czech brewing industry [Havel, 2011; Kvapil, 2015]. Cheap beer is also imported from abroad, especially from Poland and Hungary, where the production is not at the same level as in the Czech Republic.

A distinct group of customers are young people and women who prefer sweet beer. The Staropramen Brewery targeted this group when introducing a low-alcohol sweet beer called Staropramen Cool Lemon in 2010 [Hrdličková \& Šenk, 2013]. This new beer segment underwent a massive boom in 2011 and 2012 [ČTK, 2012b; MACR, 2013; Petr, 2012b]. The sweet mixes of beer and lemonade (shandies, also known as "radlers") attracted the targeted group [Petr, 2013a; Sůra, 2015a], which resulted in a 7.5\% share in the beer market in 2012 [Hrdličková \& Šenk, 2013]. Radlers were produced in various flavours - lemon, orange, blackberry, mixed berries, vanilla, eucalyptus, and wasabi [Paloncy, 2013]. The portfolio was wide-ranging and experts forecast a decrease in demand [Hrdličková \& Šenk, 2013], which eventually occurred in 2013 [Sůra, 2015a; Vinopal, 2014]. Although one of the reasons for this appeared to be the poor weather in the summer months [Ptáčník, 2013b], the main reason was the recession. Non-alcoholic beer had a similar ascent followed by a later descent [Kütner, 2012]. The higher consumption was connected to the change in the penalty points system for car drivers. Fines for driving under the influence were increased so drivers began drinking non-alcoholic beer when they could not drink alcohol although non-alcoholic beer was not perceived as a full substitute for beer [Ptáčník, 2013a; red, 2012].

The quality of beer is based on the production process and the materials used (hops, water, malt, and brewer's yeast). The brewing process, technology, raw materials, and basic technological processes have remained the same for microbreweries, small independent breweries, and large breweries [Gembala, 2013; Morávek, 2013]. However, in some respects, the production is different. The difference is that the majority of small breweries 
actually use hops, claiming the more expensive variety means better quality; however, some small breweries also use hop extracts. Large breweries have industrial production, which must follow procedures, financial planning, so must economise somewhere, such as with the use of hop extract while guaranteeing that the quality of the beer will be consistent [Klepetko, 2015]. The extract has a certain amount of bitter substances in a specified quantity, which results in the beer always tasting exactly the same. The beer is also influenced by the quality of the water [Petr, 2015]. Microbreweries mostly sell fresh and unfiltered beer. The beer may not be filtered, pasteurised, and stabilised in the production process as is reflected in higher-quality beer. However, the flavour of the beer is inconsistent. It also has a much lower shelf life, which effectively prohibits its sale to commercial networks [Maier, 2013; Morávek, 2013]. Some breweries are forced by supermarket networks to brew amounts of beer higher than their production capacity. The lack of capacity is solved by producing beer in a competing brewery. For example, non-premium beers such as Primus and Klasik have been produced in the Platan Brewery in Protivín [Maier, 2012]. This behaviour appears rather bizarre considering there is no ownership connection.

Initially, premium and special beers had a very low share of the beer market because of the Communist Era and the pressure from supermarkets selling low-cost beer. The gap in the market became saturated by the micro and mini breweries boom after 2005 . The rise and recent boom of microbreweries are connected to special beers [Gembala, 2013] and the tax allowance for small breweries [Hergetová, 2015b; Morávek, 2013] plus the willingness of consumers to try new beers [PP Agency, 2013; Vinopal, 2015]. All these factors enabled the microbreweries to penetrate the market and resulted in approximately 350 mini and microbreweries operating in the Czech Republic in 2016; a number that is still growing. Microbreweries are usually located in small towns (up to 2,000 inhabitants) and cities with over 100,000 inhabitants [Čechová, 2011], while the density of breweries serves as an attractive tool for the region because of beer tourism [Vacl, 2014]. Micro and mini breweries are locally oriented and a brewery's distribution is usually only through its own restaurant or within a retail network in a maximum distance of $50 \mathrm{~km}$ [Morávek, 2013; Petr, 2009]. Nevertheless, not all regions are saturated. For example, the Liberec region has the lowest density of breweries in the Czech Republic [Čechová, 2011]. Visiting microbreweries means drinking a special beer with a "story" [Vacl, 2014]. Additionally, microbreweries in the country are selling their beer underpriced [Kvapil, 2015]. Most microbrewery owners started to brew beer as a hobby and later upgraded their production. Some owners use the differentiation strategy while others state differentiation whereas, in reality, the production is based on a low-cost strategy [Klepetko, 2015].

\subsubsection{Customer behaviour}

The frequently mentioned financial crisis (2009) also changed consumer behaviour in three ways. The first step was a rapid decrease in consumption as mentioned in the previous section. Consumption in 2010 was 10 litres per inhabitant lower than the previous year and this could especially be seen in attractive tourist locations [Petr, 2010a; 2010c]. The next step was switching the point of consumption from pubs to households and the change in packaging (PET bottles). The deepening crisis diversified the beer market (as mentioned above) and some customers started to prefer special beers. These special beers revitalised 
the pubs [Janouš, 2016; Petř́iček, 2016] because such beer is not distributed in bottles. Changing customer behaviour is also influenced by increasing market diversification and especially by the fact that many alcohol consumers now drink wine [Veselý, 2011].

The main change in consumer behaviour in this period was the switch in beer consumption from pubs to homes [Čechová, 2011; Morávek, 2013; PP Agency, 2015; Procházková, 2010]. The distribution change (switching consumption) began in 2009 [Klepetko, 2015] and the percentage share of off-trade consumption (consumption is not at the point of sale) increased [Klepetko, 2015; Králová, 2010b; Šenk \& Hrdličková, 2014; Štefek, 2013; MarketLine, 2013; 2014]. The majority of authors [Klepetko, 2015; Šámal \& Falge, 2015; Urbanová, 2012; Van de Walle, 2015] present the percentage change as rapid (around 10\% within 3 years). Nevertheless, the beer industry profile of the Czech Republic had a slight increase (see Table 4) in off-trade consumption only. The beer was specifically sold in supermarkets due to customer price sensitivity. The reason for this behaviour was the economic crisis and tax increases [MACR, 2013; 2014; 2015; Morávek, 2013]. A further reason appears to be the lack of time for meeting friends in pubs. The breweries were forced to change their beer distribution strategies, which decreased the overall profits because the margin on draft beer was higher and at the same time the supermarket chains forced the breweries to decrease the price [Kvapil, 2015; Štefek, 2013].

Table 4 | Beer distribution in the Czech Republic: \% Share, by Volume

\begin{tabular}{|c|c|c|c|c|c|c|c|c|c|c|}
\hline & 2004 & 2005 & 2006 & 2007 & 2008 & 2009 & 2010 & 2011 & 2012 & 2013 \\
\hline On-trade & 59.1 & 59.1 & 59.1 & 56.9 & 56.3 & 56 & 55.7 & 55.4 & 55 & 54.5 \\
\hline \multicolumn{2}{|l|}{$\begin{array}{l}\text { Supermarkets I } \\
\text { hypermarkets }\end{array}$} & & & 23.3 & 23.9 & 24.5 & 24.5 & 24.8 & 25.2 & 25.7 \\
\hline Specialist retailers & 12.2 & 12.2 & 12.2 & 12.8 & 12.8 & 12.8 & 12.8 & 12.8 & 12.8 & 12.8 \\
\hline Service stations & & & & & & & & 3.5 & 3.5 & 3.5 \\
\hline Other & 28.7 & 28.7 & 28.7 & 7 & 7 & 7 & 7 & 3.5 & 3.6 & 3.5 \\
\hline
\end{tabular}

Source: [Datamonitor, 2005]

The trend for domestic beer consumption is also associated with the type of packaging [Tácha, 2011]. Beer in PET bottles was first introduced by Staropramen (q-pack bottles) in 2004 [Kozáková, 2004; Economia, 2006], but was unsuccessful and the main entrance onto the market was by the Heineken group in 2008 [MACR, 2014; Tůma, 2011]. The special 1.5 litre bottles are much easier to transport and the price per beer is lower than traditional glass bottles [Bouc, 2011b; Petr, 2010b]. This type of packaging became popular [Bouc, 2011a; MACR, 2014; PP Agency, 2013] between 2010 and 2011 and there was an $80 \%$ relative growth in PET bottles [MACR, 2013; Veselý, 2011]. PET bottles were not used by all the breweries and not for the whole beer portfolio. They were first used for cheaper brands of beer then later expanded to include other brands as an extension of the packaging services. Sometimes this packaging diversification cannibalised the rest of the product portfolio - especially glass bottles [Petr, 2013a].

PET bottles were initially not regarded as appropriate packaging for beer [Petr, 2012c], and several breweries refused to use them. The main objectors were Budweiser 
Budvar and Bernard [Kütner, 2012; Petr, 2012c], as they perceived it would degrade the quality of the beer. However, the PET bottles used for beer are different from those used for soft drinks. PET beer bottles are produced from Actis B material and hold the quality of beer at the required level [Kociánová, 2011; Petr, 2010b] although glass bottles are still better [Bouc, 2011b]. The durability of the quality is not only based on material but also on filling the bottles in such a way that there is no additional air in the bottle. The other advantage is the price of the filling process. Micro-breweries use PET bottles because of cheaper production and easier distribution [Maier, 2013; Petr, 2009]. The second reason is the production of special unpasteurised beers that have a shorter shelf life. The disadvantage of PET bottles is the lack of recyclability.

The pricing strategies were analysed by Maier [2012] and Pilsner Urquell was the price leader. Microbreweries adopted the low-cost strategy when they began [Petr, 2010a]; nevertheless, this was a strategic mistake, as they were not able to compete against industrial breweries because of high production costs. Larger breweries felt the need for wider distribution than the local ones, which was satisfied by the nationwide supermarket chains although the breweries were pressured into lowering the production price [Datamonitor, $2011 ; 2013]$. Nevertheless, breweries can increase the price of barrelled (keg) beer easier than they can with bottled beer [Maier, 2012]. The price sensitivity of beer applies to low-income consumers who prefer trade-off consumption. The average prices of bottled beer have been increasing very slowly (see Table 5). Considering generic strategies, either the differentiation or low-cost strategies are used by the industrial breweries. They have different types of beer (a wide-ranging portfolio) to satisfy all customer groups. On the other hand, microbreweries exclusively use the differentiation strategy.

Table 5 | Average price of bottled beer 2011-2016

\begin{tabular}{|l|c|c|c|c|c|c|}
\hline & $\mathbf{2 0 1 1}$ & $\mathbf{2 0 1 2}$ & $\mathbf{2 0 1 3}$ & $\mathbf{2 0 1 4}$ & $\mathbf{2 0 1 5}$ & $\mathbf{2 0 1 6}$ \\
\hline January & $\mathbf{1 0 . 1 1}$ & $\mathbf{1 0 . 0 0}$ & $\mathbf{1 0 . 7 0}$ & 10.84 & 11.02 & 11.16 \\
\hline February & 10.19 & 10.00 & 10.50 & 10.76 & 10.57 & 11.32 \\
\hline March & 10.10 & 9.90 & 10.60 & 10.49 & 10.85 & 11.29 \\
\hline April & 10.01 & 10.20 & 10.80 & 10.48 & 10.62 & 11.63 \\
\hline May & 10.12 & 10.00 & 10.70 & 10.87 & 10.37 & 11.39 \\
\hline June & 9.92 & 10.00 & 10.50 & 10.53 & 10.97 & 10.92 \\
\hline July & 10.10 & 10.10 & 10.50 & 10.80 & 10.90 & 11.06 \\
\hline August & 10.11 & 9.80 & 10.40 & 10.83 & 10.77 & 11.33 \\
\hline September & 9.97 & 10.00 & 10.30 & 10.63 & 10.63 & 11.04 \\
\hline October & 9.97 & 10.50 & 10.70 & 10.80 & 10.58 & 11.28 \\
\hline November & 9.91 & 10.60 & 10.50 & 10.14 & 10.37 & \\
\hline December & 9.78 & 10.40 & 10.60 & 10.42 & 10.57 & \\
\hline
\end{tabular}

Source: [CZSO, 2015a; 2015b; 2015c; Kratochvílová, 2016a; 2016b; 2016c] 


\section{Discussion and conclusions}

Brewery strategies have been influenced by several of the previously mentioned factors. The mistakes and successes and the main forces that shaped the brewing industry and the strategies of particular brewery groups (large, medium-sized, and microbreweries) are discussed. These discussions are ordered chronologically according to the decades.

The brewing industry had the opportunity for a new beginning in 1990 following the Velvet Revolution. The production and distribution were locally oriented, with customers usually drinking local beer and not requiring other brands. The only brands that had national coverage were Budweiser Budvar, Pilsner Urquell, and Staropramen, which were perceived as premium beers. The brewing industry was deemed to be a relatively stable and attractive industry, considering the Czechs ranked first in global beer consumption. The breweries were owned by the state and the planned economy of that time did not apply strategic thinking. However, restitution and privatisation processes changed the ownership structure. Many domestic investors and investment funds who did not apply ownership rights bought the majority of breweries as their primary interest was in the size of the dividends. Foreign financial institutions such as the Nomura investment bank took a similar approach. These groups did not have development strategies for the breweries; their main interest was only in flipping the stocks to make a profit. There were some cases where the managers had their own profit (connected to a lack of ethics in this era) from the brewery as was similar in other industries. The breweries followed a "nonstrategy" - a stuck in the middle strategy. The reason for this behaviour can be seen in the lack of experts in the economic field after the Velvet Revolution. University education in economics in the Czech Republic had been focused on a planned economy rather than market economies and strategies.

The strategic behaviour appeared to be the result of privatisation and the subsequent acquisitions, where the Big 5 group of breweries controlled $80 \%$ of the market. Their strategy was to gain maximum market share to achieve an economy of scale. This lowcost strategy was successful due to this economy of scale and investment into technology improvements, which increased production and reduced costs. The medium-sized and small breweries were not able to save (or earn) enough money to buy the same technology. This resulted in market concentration and the pressure to gain a majority market share via price wars. The price wars broke out due to a lack of consumer requirements. Customers were not used to high standards regarding the quality or the taste of the beer. Customers usually drank local beer and only tasted other beers when visiting other regions. This lack of comparison meant some breweries could produce low-quality cheap beer as their customers behaved not as customers, but as consumers. The former regional patriotism changed into low brand loyalty and trade-off consumption. Supermarket chains that pressured breweries to reduce the price of bottled beers also supported the low-cost strategy of big breweries. The remainder of the market was split between more than 60 breweries that were unable to compete with these low prices. Some of these tried to differentiate by introducing speciality beers, but their efforts proved fruitless and many medium-sized breweries went bankrupt. The split of former Czechoslovakia in 1993 also exacerbated the closing of breweries in South Moravia, a region that borders Slovakia.

The collapse of medium-sized breweries and the price wars continued into the new millennium. Although market concentration strengthened, the majority of the market 
was held by the eight largest breweries, which had invested in new brewing technologies. These technologies enabled them to produce more beer at lower prices, but with a standard taste. The majority of the beer production tasted the same and it was light cheap beer, often referred to as Eurobeer. The large breweries supported sales with new bottle designs and franchise pubs (the first was the Švejk restaurant concept, followed by Potrefená husa and Kozlovna). Considering the industry development in this period, the large breweries reflected the environmental forces within their strategies and were successful. On the other hand, the main mistake of medium-sized breweries was that they were not able to buy new technologies. If they had tried differentiation at the very beginning of the price wars, they may have survived. Nevertheless, it is uncertain if customers were prepared for differentiation strategies, which were started by Bernard and the rise of microbreweries. A further mistake was in brewing 10 and 12 degree beers at the beginning when were not able to compete with these types of beer due to changing taste and prices. They later adopted the practice of brewing special beers, which opened up a new way to target new customers. The rise of microbreweries in 2005 started the critique of poor quality Eurobeer and the increase in premium and special beer consumption (see Figure 5). The first decade of the new millennium faced waves of reduced consumption and an increase due to the economic situation in the Czech Republic and when joining the EU in 2004.

Figure 5 | Beer types by market share

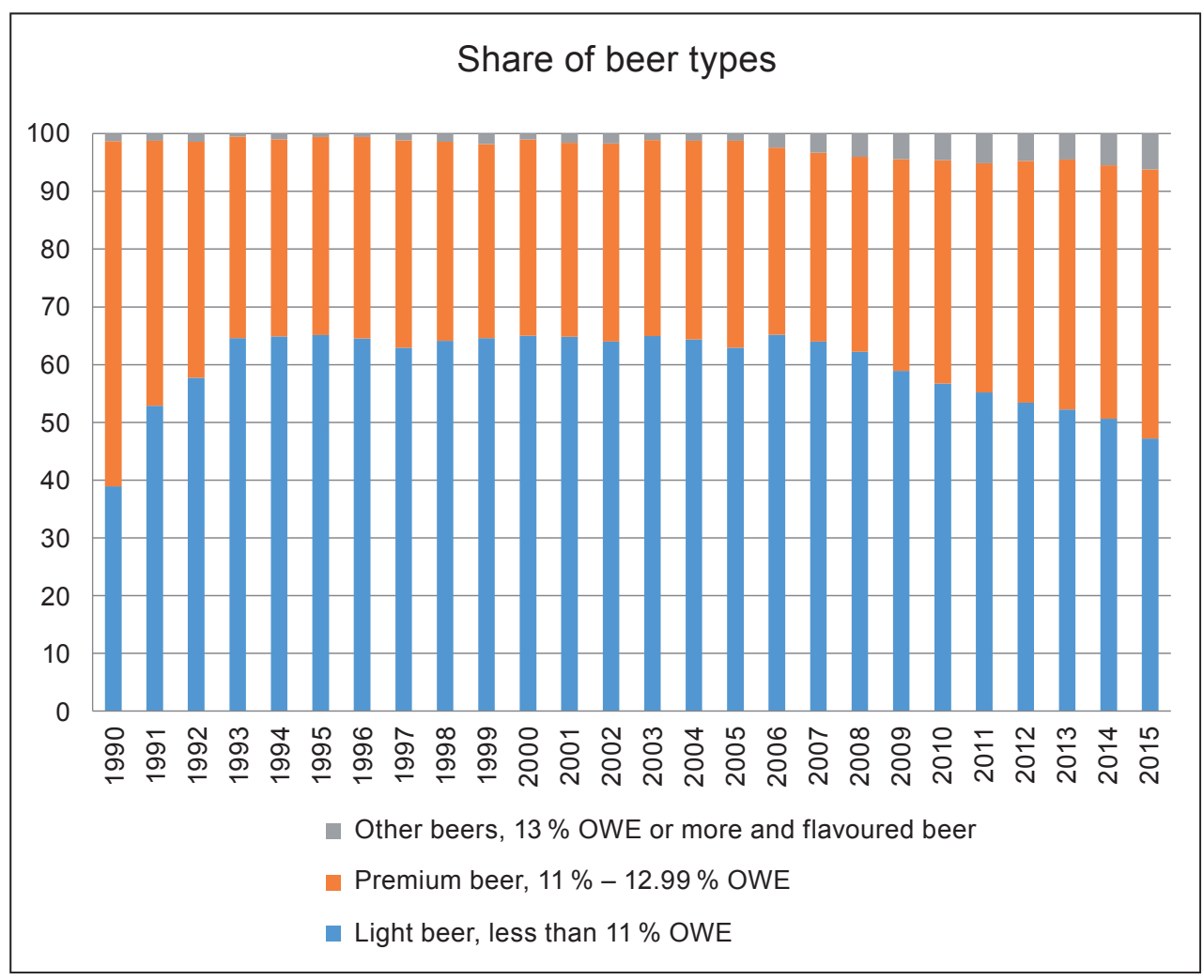

Source: authors' own calculations 
The brewing industry was at its most dynamic due to the economic crisis in 2009 . The rapid decline in beer consumption was caused by the economic crisis while the increase in taxation completely changed consumer behaviour and the breweries' strategy. The rise of the differentiation strategy stopped and all breweries were made to think about where to sell their products. The majority of production was sold in supermarkets (trade-off consumption) at low prices while the use of PET bottles led to even lower prices. This situation did not last for long as production increased through exports. Premium and special beers were primarily exported (as they are today). The breweries had to adopt two different strategies: a low-cost strategy for the domestic market and a differentiation strategy for the export market, both of which are connected to product diversification. Premium and special beers have recently been pushed onto the domestic market partly by customers demanding a change. Special beers, sweet beer mixes and non-alcoholic beers have enhanced the beer portfolio. These requirements for change also sparked the microbrewery boom. Customers today are very different from consumers at the beginning of the 1990s. There are many demanding customers who require quality beer and are willing to pay more for it. Nevertheless, there are still customers who demand low prices. The breweries (or brewery groups) usually have a wide-ranging portfolio to satisfy all their customers. They use differentiation and low-cost strategies for different products in their portfolio. Although this can be risky, the brewing industry in the Czech Republic confirms that it works for large breweries. Medium-sized breweries usually flow between differentiation and low-cost strategies; some use the stuck in the middle or hybrid strategy, which due to the Czech beer culture actually works. Microbreweries should use differentiation or focus differentiation (locally oriented) strategies. The majority are now heading in this direction. Nevertheless, there are an increasing number of entrepreneurs who externally mention a differentiation strategy based on beer quality but their production is actually based on a low-cost strategy. They usually exploit the microbrewery trend to generate income without considering that the operation of a microbrewery should be based on a passion for beer.

The above-mentioned information shows that for the majority of the time in question a low-cost strategy was used. However, strategic waves where the differentiation strategy appeared and more recently resisted can be observed. Nevertheless, these waves became shorter and shorter and nowadays, the differentiation strategy has its own place in the brewing industry. The present-day beer market appears to be mature and includes different types of customers who exactly know their requirements - this opens up different market segments that did not exist after the Velvet Revolution. Breweries should be aware of customer requirements because they change more often than before. Large breweries should cover as many beer market segments as they possibly can. Medium-sized and microbreweries should stay focused on their current portfolio and offer special beers for special occasions from time to time. The important point of formulating a brewing strategy is implementing it in everyday processes. Differentiation should be implemented at all levels and processes; the same as the low-cost strategy.

Our research may have been limited in our perception and interpretation of a particular topic while a further limitation can be observed in terms of the resources found and selected for the historical research. There was a lack of resources available for the first decade and due to this, our point of view could have changed. Another limitation 
can be seen in the statistics of the brewing industry, as a whole-time series for particular variables are lacking.

These limitations were partially lowered by interviewing managers from the brewing industry as a validation source. Nevertheless, there were only four interviews and we perceive that more interviews would have helped us. However, the level of information gained was sufficient. The results of our historical research correspond to our respondents' answers. Some respondents added details about particular breweries; nevertheless, the details support the behaviour of the whole industry.

This article is our first step in analysing the beer industry. Historical knowledge is important for orienting ourselves to strategic decision-making and market reactions. Future research will be based on the contemporary strategies of particular breweries (large, medium-sized, and microbreweries separately) and on an analysis of customer requirements.

\section{References}

ADAMČIKOVÁ, N. and KÖNIGOVÁ, M., 2011. Lidé méně pijí pivo. Bude levnější. Právo, September 17. ANDERSON, R., 1999. Czech Beer Set for European Revival: Foreign Interest Has Improved Prospects for the Industry. Financial Times, April 26.

ANDERSON, R. and WILLMAN, J., 1999. SAB Is Prepared for More Beer and Scuffles: John Willman and Robert Anderson on the Brewer That Now Dominates Central Europe. Financial Times, October 8, 26.

ANDREW, D. P. S., PEDERSEN, P. M. and MCEVOY, C. D., 2011. Research Methods and Design in Sport Management. Human Kinetics. ISBN 978-0-7360-7385-1.

ANOPRESS IT, 2016. O nás - Anopress IT, a. s. - dodavatel profesionálního monitoringu médií [online]. [accessed June 29, 2016]. Available at:

http://www.anopress.cz.zdroje.vse.cz/anopress

BARTÁK, P., 2000. Sázka na speciální a krajová piva vychází. Profit, 11.

BASAŘOVÁ, G. and HLAVÁČEK, I., 1998. České pivo [online]. [accessed September 10, 2016]. Available at: http://www.cbdb.cz/kniha-78793-ceske-pivo

BĚLOHOUBEK, A., 1874. Pivovarnictví [online]. [accessed September 10, 2016]. Available at: http://kramerius.mzk.cz/search/handle/uuid\%3A4f8f33ae-0b5c-4546-9775-ecd2cb7eaf4f

BERÁNEK, J., 1997. Koncentrace je v pivovarnictví celosvětovým trendem. Hospodářské noviny, October 17. ISSN 0322-7774.

BÖHM, J., 2008. Pivo ted’ chutná jako sodovka, ř́ká expert. Lidové noviny, March 27. ISSN 0862-5921.

BOHUNĚK, B., 2002. Česká pivní jistota. Marketing \& Media, 14.

BOLAND, V., 1997. Czech Brewers Seek Solace Abroad: Czechs Drink More Beer Than Anyone Else, but Breweries Are Barely Profitable. Financial Times, March 11.

BOUC, F., 2011a. Zlevňování by poškodilo image piva. Lidové noviny, May 27.

BOUC, F., 2011b. Bez inovací se neobejde ani pivo. Lidové noviny, March 29.

BUDÍNSKÝ, L. and ZÁZVORKA, J., 2008. České EUROPIVO. Instinkt, May 5.

ČECHOVÁ, K., 2011. Dříve pivo vařili v každé vesnici. Dnes je v kraji nejméně pivovarů. Sedmička, November 10. 
CZSO, 2015a. Cena lahvového piva - rok 2011 [online]. [accessed November 7, 2016]. Available at: https://www.czso.cz/csu/czso/1-pivo_2011

CZSO, 2015b. Cena lahvového piva - rok 2013 [online]. [accessed November 7, 2016]. Available at: https://www.czso.cz/csu/czso/1-pivo_2013

CZSO, 2015c. Cena lahvového piva - rok 2012 [online]. [accessed November 7, 2016]. Available at: https://www.czso.cz/csu/czso/1-pivo_2012

CHLÁDEK, L., 2007. Pivovarnictví. ISBN 978-80-247-1616-9.

CHMELIKOVA, G. and SABOLOVIC, M., 2012. The Economics of Beer Processing. In Ayman Amer Eissa (ed.). Trends in Vital Food and Control Engineering. B.m.: InTech.

ISBN 978-953-51-0449-0.

ciz, 1999. Malé pivovary letos zvolna pozvedají hlavu. MF Dnes, September 9, 13.

ciz, 2000. Speciální piva si už našla místo na trhu. MF Dnes, February 29.

COOK, J., 1999. Czech Beer Dispute Comes to a Head: Consolidation Could Allow Brewers to Tap Their Market Fully. Financial Times, September 4.

ČTK (Czech News Agency), 2012a. Budějovickému Budvaru se daří. Lidové noviny, July 31.

ČTK, 2012b. Produkce pivovarů letos roste. Hlavně díky mixům. Hospodářské noviny, July 31.

DORČÁKOVÁ, J., 2015. Budoucnost piva v hospodě? Široká nabídka a pestrost! Horeka, September 29.

DROZDOVÁ, J., 2015. Situační a výhledová zpráva Chmel, Pivo [online]. [accessed January 21, 2017]. Prague: Ministry of Agriculture of the Czech Republic. Available at: http://www.apic-ak.cz/data_ak/16/k/ChmelPivoSVZ1512.pdf

ECONOMIA, 2006. Pivo prodá po všech stránkách povedené léto. Regal, 3.

ECONOMIA \& HOSPODÁŘSKÉ NOVINY, 2013. Největším českým pivovarům klesl zisk, musejí se více prosazovat v cizině. Ekonom, July 11.

EDWARDS, A. and SKINNER, J., 2010. Qualitative Research in Sport Management. Oxford: Taylor \& Francis. ISBN 978-1-136-43636-9.

eko \& ČTK, 2000. Jihočeši zavřou pivovary Platan a Regent. MF Dnes, March 22.

FIEDLEROVÁ, J., 1996. Nad malými pivovary se pomalu, ale jistě smráká. Profit, May 15.

FILLA, P., 1999. Skrytá nevyhlášená cenová i konkurenční válka mezi velkými a malými pivovary nadále pokračuje. Hradecké noviny, May 19.

FRANCOVÁ, P., 2010. Rána pro Louny: Heineken končí. Lidové noviny, January 26.

FREEMAN, R. E., 2010. Strategic Management: A Stakeholder Approach. Cambridge University Press. ISBN 978-0-521-15174-0.

GARCÍA, J. A. M. and CARO, L. M., 2009. Understanding Customer Loyalty Through System Dynamics : The Case of a Public Sports Service in Spain. Management Decision, 47(1), 151-172, https://doi.org/10.1108/00251740910929768

GEMBALA, O., 2013. Klasické, tradiční, české. Barlife, 1.

GRBICH, C., 2012. Qualitative Data Analysis: An Introduction (2nd. ed.). London: SAGE Publications. ISBN 978-1-4462-7179-7.

GREEN, P. S., 1999. Small Czech Brewers Decline as Giants Battle for Dominance. International Herald Tribune, September 17.

GREENHOUSE, S., 1990. Capitalist Ferment at Czech Brewer. The New York Times, May 16.

HAVEL, P., 2011. Nárůst daně snížil kvalitu piva. Lidové noviny, August 15. 
HENDL, J., 2005. Kvalitativní výzkum: základní metody a aplikace. Praha: Portál.

ISBN 80-7367-040-2.

HERGETOVÁ, M., 2015a. AB InBev kupuje rivala SABMiller. Ekonomika ČT24, October 13.

HERGETOVÁ, M., 2015b. Výroba českého piva roste. Ekonomika ČT24, April 14.

HRDLIČKOVÁ, L. and POLJAKOV, N., 2015. Ženy mají pivo rády, jen mají sofistikovanější chut' než muži, říká šéfka SABMiller. Hospodářské noviny, March 11.

HRDLIČKOVÁ, L. and ŠENK, M., 2013. Prodeje Prazdroje má podržet export a nealko pivo. Hospodářské noviny, November 22.

JANDA, K. and MIKOLASEK, J., 2011. Success in Economic Transformation of the Czech Beer Industry and Its Social Costs and Benefits. Transformations in Business and Economics, 10(3), 117-137. ISSN 16484460.

JANOUŠ, V., 2016. Pivní speciály. Zachrání hospody? Pražský deník, April 26.

JILEMNICKÝ, M. S., 2006. Malé pivovary: nové lahve nás zničí! Nymburský deník, April 5.

JUNEK, A., 2004. Na trhu je dost prostoru pro velké i malé pivovary. Hospodářské noviny, September 20.

KABELÁČOVÁ, L., 2004. Velká pivní blamáž. Týden, October 3.

KAIN, P., 2015. Šéf Pivovarů Lobkowicz: Číňané z nás udělají velkou pivovarnickou skupinu. Hospodárské noviny, September 14.

KALÁB, V. and MAŘíK, M., 2004. Evropa se otevřela malým pivovarům. Hospodářské noviny, December 29.

KALÁB, V., 2005. Malým pivovarům se loni začalo dařit. Hospodářské noviny, March 17.

KING, N. and MURRAY, S., 1994. Privatization. The Wall Street Journal, Europe, July 29.

KLEBAN, J. and NICKERSON, I., 2012. To Brew, or Not to Brew - That Is the Question: An Analysis of Competitive Forces in the Craft Brew Industry. Journal of the International Academy for Case Studies, 18(3), 59-81. ISSN 1078-4950.

KLEPETKO, B., 2015. Pivní kultura v Česku. Hyde park ČT 24, April 14.

KLOS, R. and MACKŮ, P., 2002. Pivovary bojují s přesilou netradičními výrobky. MF Dnes, October 1.

KŇOUREK, T. and MRÁZEK, T., 2002. Pivovarů začíná po útlumu opět přibývat. Hospodářské noviny, May 3.

KOCIÁNOVÁ, Š., 2011. Image piva jako součást pivní kultury. Strategie, 18(1), 7.

KORBEL, P., 2003. Velcí posilují. Hospodářské noviny, March 19.

KOZÁKOVÁ, M., 2004. Obaly roku 2004. Marketing \& Media, 5(51), 29.

KRÁLOVÁ, T., 2010a. Světoví obři šlapou po tradici. EURO, February 15.

KRÁLOVÁ, T., 2010b. Tichá vzpoura pivařů. EURO, November 22.

KRATOCHVÍLE, A., 2005. Pivovarství českých zemí v proměnách 20. století. Praha: Výzkumný ústav pivovarský a sladařský. ISBN 978-80-86576-16-9.

KRATOCHVÍLOVÁ, L., 2016a. Indexy cen zemědělských výrobců, průmyslových výrobců a indexy spotřebitelských cen potravinářského zboží - prosinec 2014 [online]. [accessed November 7, 2016]. Available at: https://www.czso.cz/csu/czso/indexy-cen-zemedelskych-vyrobcuprumyslovych-vyrobcu-a-indexy-spotrebitelskych-cen-potravinarskeho-zbozi-prosinec2014-znmhodzjid

KRATOCHVÍLOVÁ, L., 2016b. Indexy cen zemèdělských výrobců, průmyslových výrobců a indexy spotřebitelských cen potravinářského zboží - prosinec 2015 [online]. [accessed November 
7, 2016]. Available at: https://www.czso.cz/csu/czso/indexy-cen-zemedelskych-vyrobcuprumyslovych-vyrobcu-a-indexy-spotrebitelskych-cen-potravinarskeho-zboziprosinec-2015

KRATOCHVÍLOVÁ, L., 2016c. Indexy cen zemědělských výrobců, průmyslových výrobců a indexy spotřebitelských cen potravinářského zboží - záŕí 2016 [online]. [accessed November 7, 2016]. Available at: https://www.czso.cz/csu/czso/indexy-cen-zemedelskych-vyrobcuprumyslovych-vyrobcu-a-indexy-spotrebitelskych-cen-potravinarskeho-zbozi-zari-2016 KUCIEL, M., 2008. Na židli s kopýtky. Týden, December 1.

KÜTNER, D., 2012. Jiří Boček: Loni nám pomohl export, byl nejvyšší v historii. E15, January 17. KVAPIL, L., 2015. Levné pivo kazí trh. Ekonom, November 26.

LARIMO, J., MARINOV, M., and MARINOVA, S., 2006. The Central and Eastern European Brewing Industry since 1990. British Food Journal, 108(5), 371-384, https://doi.org/10.1108/00070700610661349

LAVIČKA, V., 2012. Nové tažení AB InBevu uvádí trh do varu. Hospodářské noviny, June 27.

LAVIČKA, V., 2015. Pivovarnická jednička AB InBev má zájem o majitele Plzeňského Prazdroje. Hospodářské noviny, September 17.

MADDEN, N., 1997. End of Era for Czech Beer Business. Marketing Magazine, March 3.

MAIER, T., 2012. Modelling Brewing Industry Pricing. Agris On-Line Papers in Economics \& Informatics, 5(4), 135-142, https://doi.org/ 10.7160/aol.2016.080409

MAIER, T., 2013. Selected Aspect of the Microbreweries Boom. Agris On-Line Papers in Economics \& Informatics, 5(4), 61-69. ISSN 18041930.

MAIER, T. and FABIANOVA, A., 2011. Economic Aspects of Setting up a Microbrewery Restaurant. Kvasny prumysl, 57, 330-336, https://doi.org/10.18832/kp2011037

MARINOV, M. A. and MARINOVA, S. T., 2015. Marketing Strategies of Foreign Breweries in Central and Eastern Europe [online]. [accessed October 14, 2016]. Available at: https://www.researchgate.net/publication/267719922_Marketing_Strategies_of_ Foreign_Breweries_in_Central_and_Eastern_Europe

MAUKŠ, I., 1997. Na jižní Moravě zanikají pivovary. Lidové noviny, December 5.

MF DNES, 2006. Deset minipivovarů v Česku. MF Dnes, August 28.

MACR (Ministry of Agriculture of the Czech Republic), 2013. Český chmel 2013 / Czech Hops 2013. Prague: MACR. ISBN 978-80-7434-051-2.

MACR, 2014. Český chmel 2014 / Czech Hops 2014. Prague: MACR. ISBN 978-80-7434-161-8.

MACR, 2015. Český chmel 2015 / Czech Hops 2015. Prague: MACR. ISBN 978-80-7434-246-2.

MORÁVEK, D., 2013. Regiony a minipivovary zažívají boom. Euro, February 21.

MOTEJLEK, M., 1998. Boj o zákazníka na českém pivním trhu se vede všemi prostředky. Lidové noviny, July 23.

MRÁZEK, T., 2004. Malé pivovary ustupují, finančně nestačí. Hospodářské noviny, April 22.

MURRAY, S., 1995. Prazdoj's Beer: Rich History, Poor Sales - Pilsner Urquell Can't Prevail on Its Name Alone. The Wall Street Journal, Europe, June 16.

NĚMEC, J., 2014. Malá česká pivní revoluce. Ekonom, August 7.

NEWBERRY, J., 1993. Czech Beer Industry Loses Its Froth. Central European. 36. ISSN 09622543.

PETR, M., 2009. V Česku vyrostou další nové pivovary. Hospodářské noviny, January 20.

PETR, M., 2010a. Boom malých pivovarů v Česku pokračuje navzdory krizi. Hospodářské noviny, March 26. 
PETR, M., 2010b. Domácí pivní trh prožívá nejhorší rok v polistopadové historii. Hospodářské noviny. October 27.

PETR, M., 2010c. PET lahve "frčí, už je zavádějí i minipivovary. Hospodářské noviny, November 18.

PETR, M., 2012a. Majitel Staropramenu vyzkouší v Česku další značky piv. Hospodářské noviny, June 19.

PETR, M., 2012b. Převrat v pivovarnictví - na trhu se konečně uchytila ovocná piva. Hospodářské noviny, December 18.

PETR, M., 2012c. Služba pivařům, nebo zločin? Pivo v PET lahvích rozděluje české pivovary. Hospodářské noviny, April 16.

PETR, M., 2013a. Prodeje pivovarů zachraňuje export. Hospodářské noviny, March 29.

PETR, M., 2013b. Pivní trh zachraňují radlery a export, potvrzují čísla Prazdroje. Hospodářské noviny, January 28.

PETR, M., 2015. I velké pivovary mohou vařit dobrá piva, připouští Stanislav Bernard. Lidové noviny, August 9.

PETŘíČEK, M., 2016. Velké pivovary lákají na speciály. Podívejte se na jejich výrobu [online, VIDEO]. [accessed October 7, 2016]. Available at: http://ekonomika.idnes.cz/jak-se-varipivo-ve-staropramenu-dop-/ekoakcie.aspx?c=A160915_153235_ekoakcie_map1

PIKE, J., 2010. Soukromé pasti českého piva. Lobby, 12(3). ISSN 1212-4524.

PÍREK, I. and RYSKOVÁ, S., 1997. Výstav piva roste, počet pivovarů klesá. Českomoravský Profit, 8, 10-11. ISSN 1211-5428.

PITLÍK, J., 1996. Přežijí malé pivovary? Profit, October 15.

PALONCY, M., 2013. Ponořte se do světa piva [online]. Novinky.cz [accessed November 16, 2016]. Available at:

https://www.novinky.cz/zena/zdravi/320707-ponorte-se-do-sveta-piva.html

PORTER, M. E., 2008. On Competition. Boston: Harvard Business School Press. ISBN 978-1-4221-2696-7.

PP AGENCY, 2007. Drinks Union Is an Important Player on the Czech Beer Market. Czech Business \& Trade, 5/6, 18. ISSN 12112208.

PP AGENCY, 2013. Brewing Industry - Innovative Offering and Return of Export Dynamics. Czech Business \& Trade, 1, 15-17. ISSN 12112208.

PP AGENCY, 2015. Beer Brewers Are Assisted by Growing Exports. Czech Business \& Trade, 1, 29-31. ISSN 12112208.

PRCHAL, M., 2012. Hledá záchranu ve Staropramenu. Ekonom, 56(16), 34. ISSN 1210-0714.

PROCHÁZKOVÁ, M., 2010. Maxiláhev slaví úspěch. Podnikatel, February 19.

PŠENIČKA, J., 2001. Vzpoura trpaslíků. EURO, July 23.

PTÁČNÍK, S., 1999. Postupující koncentrace je hrozbou pro menší a střední české pivovary. Právo. ISSN 1211-2119.

PTÁČNÍK, S., 2010. Pivovarníci dál lobbují proti vyšší dani. Právo, January 25.

PTÁČNíK, S., 2013a. Piva se v tuzemsku vypilo méně, pivovary podržel export. Právo, August 28.

PTÁČNÍK, S., 2013b. Nový fenomén: Češi si oblíbili pivní mixy. Právo, March 8.

PULEC, J., 2016. Integration of the Czech Brewing Industry into Global Production Networks. AUC GEOGRAPHICA, 51(1), 47-59, https://doi.org/10.14712/23361980.2016.5 
PYŠNÝ, T. and ŽUFAN, P., 2006. Globalization Influences in Czech Brewing. Agrární perspektivy, $15,571-575$.

ŘEBOUN, O., 2013. Z malých je pivo chutovější. Literární noviny, April 18.

red, 1999. Nízkostupňová levnější piva již tolik zákazníky nepřitahují. Právo, July 26.

red, 2012. Pivní kultura se u nás mění, sice pomalu, ale jistě. Parlamentní listy, November 22.

ROCKS, D., 1996. Czech Beer Business Goes Modern CHANGING HABITS / Arrival of capitalism has brought culture shock to brewers and drinkers. The Globe and Mail, April 26.

ROCKS, D., 1997. Consolidation Talk Grips Czech Brewing Industry. The Wall Street Journal, Europe, September 3.

ŠÁMAL, F., 2016. Zpráva o stavu českého pivovarství a sladařství za rok 2015 [online]. Český svaz pivovarů a sladoven [accessed October 3, 2016]. Available at: http://pivni.info/down/2016_hospodarske-vysledky-oboru-za-2015.pdf

ŠÁMAL, F. and FALGE, D., 2015. Zpráva o stavu českého pivovarství a sladařství za rok 2014 [online]. Český svaz pivovarů a sladoven [accessed April 10, 2015]. Available at: http://pef. czu.cz/ maiert/2015_zprava_hospodarske_vysledky_oboru_za_2014_final_20150410.pdf

SEDLÁČKOVÁ, V., 2014. Ministr zemědělství navrhuje nižší spotřební daň pro pivo. Mohla by se promítnout i do ceny [online]. Český rozhlas [accessed September 25, 2016]. Available at: https://www.irozhlas.cz/node/5936457

SEDLÁK, J., 2015. Obří fúze mění poměr sil v pivovarnictví, bezprostředně se týká i tuzemských firem. Haló noviny, November 21.

ŠENK, M. and HRDLIČKOVÁ, L., 2014. Velkým pivovarům klesá prodej v Česku, musí hledat nové zákazníky v zahraničí. Hospodářské noviny, March 13.

SHORT, M., 2008. Pivo budeme vařit v Česku. Ekonom, February 28.

ŠMEJKAL, P., 2004. Pivní trh v Česku zůstává nadále stabilní. Strategie, November 22.

SMRČKA, V., 2003. Rekordní vývoz českých pivovarů. EURO, April 7.

šmu \& hni, 2005. Přes nasycený trh s alkoholem se minipivovarům daří. Chebský deník (109).

ŠTEFEK, J., 2013. Dnešní generace pivařů je už jiná. Týden, February 18.

STELLNER, F. and POLANECKÝ, L., 2016. The Development of the Brewing Industry in South Bohemian Region in The Turn of the 20th and 21st Centuries. Kvasný průmysl, 62(2), 67-70, https://doi.org/10.18832/kp2016011

ŠTRUNC, P., 2014. Ministr zemědělství chce navrhnout nižší spotřební daň na pivo. Zprávy FTV Prima, June 19.

SŮRA, J., 2015a. V Česku loni vzniklo padesát minipivovarů. Jejich počet se blíží 300 [online]. iDnes.cz [accessed November 27, 2015]. Available at: http://ekonomika.idnes.cz/ceskozaziva-boom-minipivovaru-d3v-/ekonomika.aspx?c=A150318_153509_ekonomika_rny

SŮRA, J., 2015b. Naučíme ženy, že pivo je lepší než víno. MF Dnes, March 23.

SVEIBY, K.-E., LINARD, K. and DVORSKY, L., 2002. Building a Knowledge-Based Strategy:

A System Dynamics Model for Allocating Value Adding Capacity [online]. [accessed June 6, 2015]. Available at: https://www.semanticscholar.org/paper/Building-a-Knowledge-Based-Strategy-ASystem-Dynam-Sveiby-Linard/c94b4064ff2c5e29dfcd7701ca6701ffa7929ad3

SYROVÁTKA, P., CHLÁDKOVÁ, H. and ŽUFAN, P., 2015. Consumer Demand for Wine and Beer in the Czech Republic, and Their Mutual Influences. Acta Universitatis Agriculturae et 
Silviculturae Mendelianae Brunensis, 63(6), 2119-2125, https://doi.org/10.11118/actaun201563062119

TÁCHA, D., 2011. Soumrak piva? ForMen, 6(2), 52-54.

TRUHLIČKA, I., 2002. Klasických pivařů ubývá, ale určitě nevymřou, říká novopacký sládek. MF Dnes, October 1.

TŮMA, O., 2011. Svět českých pivařů se mění [online]. [accessed October 11, 2016] Available at: http://www.penize.cz/nakupy/226771-svet-ceskych-pivaru-se-meni

URBANOVÁ, B., 2012. Doba přeje rozmanitosti. Barlife, 9(2). ISSN 1802-2316.

VACL, J., 2008. České pivo [online]. [accessed November 2, 2016]. Available at: https://www.pivo-pivo.cz/svetpiva/clanek/3638-Ceske-pivo/index.htm

VACL, J., 2014. Microbreweries as Attractive Tourist Destinations in the Czech Republic. Annual International Conference on Business Strategy \& Organizational Behaviour (BizStrategy), 51-61, https://doi.org/10.5176/2251-1970_BizStrategy14.28

VAN DE WALLE, M. (ed.), 2015. Beer statistics 2015 edition [accessed September 4, 2016]. Available at: http://www.brewersofeurope.org/uploads/mycms-files/documents/publications/2015/ statistics_2015_v3.pdf

VESELSKÁ, E., 2005. Market Structure and Its Interactions in Beer Commodity Chain. Acta Universitatis Agriculturae et Silviculturae Mendelianae Brunensis, 53(3), 213-224, https://doi.org/10.11118/actaun200553030213

VESELÝ, J., 2011. Uniqueness of Czech Beer. Czech Business \& Trade, 4, 10-12. ISSN 12112208.

VINOPAL, J., 2015. Pivo v české společnosti v roce 2015 [online, tisková zpráva]. Centrum pro výzkum veřejného mínění [accessed June 23, 2016]. Available at:

https://cvvm.soc.cas.cz/media/com_form2content/documents/c2/a1973/f9/OR151124a.pdf

VINOPAL, J., 2014. Pivní mixy na českém pivním trhu v roce 2014 [online, tisková zpráva]. Centrum pro výzkum veřejného mínění [accessed June 23]. Available at: https://cvvm.soc.cas.cz/ media/com_form2content/documents/c2/a1825/f9/OR141202c.pdf

VŠETEČKOVÁ, V., 2006. Pivní speciály hledají cestu ke spotřebiteli. Strategie, 13(9).

ZÁKON č. 353/2003 Sb., o spotřebních daních, ve znění pozdějších předpisů. In Sbírka zákonů 2003.

ZAVADILOVÁ, T., 1998. Nad dalším osudem pivovarů Prazdroj a Radegast visí otazník. Lidové noviny, November 27.

zdz, 2000. Osm pivovarů ovládá trh. Hospodářské noviny, February 29.

zdz, 1998. Jihočeské pivovary mají zatím nejasnou budoucnost. Hospodářské noviny, October 26.

ZEMSKÉ NOVINY, 1997. Česká pivní scéna se určitě změní: Privatizace IPB zamíchá karty. ZN Zemské noviny, June 16.

ZÍKOVÁ, L., 1996. Pivovarnictví loni nebylo ztrátové. Svět hospodářství, February 29.

ŽUFAN, P. and ERBES, J., 2002. Key Driving Forces in the Czech Brewing Industry. Agricultural Economics, 48(7). 311-314. ISSN 0139-570X.

ŽUFAN, P. and PYŠNÝ, T., 2005. Bariéry vstupu v odvětví pivovarnictví v České republice / Barriers to Entry in the Czech Brewing Industry [online, Paper Presented at the Sborník prací z mezinárodní vědecké konference Agrární perspektivy XiV-znalostní ekonomika. ČzU, Praha]. [accessed July 3, 2016]. Available at: http://www.agris.cz/Content/files/main_files/73/151531/90Zufan.pdf

ZUNTYCH, Z., 2007a. Mikropivovarům se daří, lidé na dražší speciality mají. Hospodářské noviny, March 26. 
ZUNTYCH, Z., 2007b. Trh zaplaví nové pivní lahve. Hospodářské noviny, April 18.

ZÝBRT, V., 2005. Velká kniha piva: vše o pivu. Olomouc: Rubico. ISBN 80-7346-054-8.

\section{Online sources}

CZSO (Czech Statistical Office), 2016. Výsledky vyhledávání - Úvodní stránka [online] [accessed November 7, 2016]. Available at: https://www.czso.cz

DATAMONITOR, 2005-2013. Beer Industry Profile: Czech Republic [online]. [accessed September 9, 2016]. Ebsco Database.

MARKETLINE, 2013-2014. Beer Industry Profile: Czech Republic [online]. [accessed November 7, 2016]. Ebsco Database.

MJCR (Ministry of Justice of the Czech Republic), 2016. Justice.cz - úvodní strana [online].

SVIJANY, 2016. Svijany, současnost [online]. [accessed September 21, 2016]. Available at: https://www.pivovarsvijany.cz/pivovar-soucasnost/. 